NBER WORKING PAPER SERIES

SMOKESCREEN: HOW MANAGERS BEHAVE WHEN THEY HAVE SOMETHING
TO HIDE

Tanja Artiga González

Markus Schmid

David Yermack

Working Paper 18886

http://www.nber.org/papers/w18886

\author{
NATIONAL BUREAU OF ECONOMIC RESEARCH \\ 1050 Massachusetts Avenue \\ Cambridge, MA 02138 \\ March 2013
}

We are grateful to Martin Bugeja, Mike Burkhart, Ettore Croci, Daniel Ferreira, Paul Gilgen, Robert Guerrero, Simi Kedia, Peter Limbach, Daniel Metzger, Shiva Rajgopal, Daniel Sokol, and seminar participants at Catholic University of Milan, Cyprus University of Technology, University of Melbourne, New York University, University of Queensland, University of Technology Sydney, Warwick Business School, University of Western Australia, and the German Finance Association Annual Meeting in Wuppertal for helpful comments and suggestions. We thank John Connor for generously providing his extensive dataset of worldwide cartels, Jongsub Lee for generously providing his dataset of political contributions, and Ronald Masulis for generously providing his dataset of foreign independent directors. Part of this research was completed when David Yermack was a visiting professor at Erasmus University Rotterdam and Tanja Artiga González was a visiting researcher at NYU Stern School of Business. Financial support from the Swiss National Science Foundation (SNSF) and the German Academic Exchange Service (DAAD) is gratefully acknowledged. The views expressed herein are those of the authors and do not necessarily reflect the views of the National Bureau of Economic Research.

NBER working papers are circulated for discussion and comment purposes. They have not been peerreviewed or been subject to the review by the NBER Board of Directors that accompanies official NBER publications.

(C) 2013 by Tanja Artiga González, Markus Schmid, and David Yermack. All rights reserved. Short sections of text, not to exceed two paragraphs, may be quoted without explicit permission provided that full credit, including $(\mathcal{C}$ notice, is given to the source. 
Smokescreen: How Managers Behave When They Have Something To Hide

Tanja Artiga González, Markus Schmid, and David Yermack

NBER Working Paper No. 18886

March 2013, Revised December 2013

JEL No. D43,G34,L40

\begin{abstract}
$\underline{\text { ABSTRACT }}$
We study financial reporting and corporate governance in 218 companies accused of price fixing. These firms engage in evasive financial reporting strategies, including earnings smoothing, segment reclassification, and restatements. In corporate governance, cartel firms favor outside directors likely to monitor inattentively due to low attendance, other board seats, and overseas residence. When directors resign, they are often not replaced, and auditors are rarely switched. Cartel firms have unusually low CEO turnover and rely on internal management promotions. Their managers exercise stock options faster than managers of other firms. Cartel firms are large donors to political candidates. While our results are based only upon firms engaged in price fixing, we expect that they should apply generally to all companies in which managers seek to conceal poor performance or wrongdoing.
\end{abstract}

Tanja Artiga González

Swiss Institute of Banking and Finance

Rosenbergstrasse 52

CH-9000 St. Gallen, Switzerland

tanja.artigagonzalez@unisg.ch

Markus Schmid

Swiss Institute of Banking and Finance

Rosenbergstrasse 52

CH-9000 St. Gallen, Switzerland

markus.schmid@unisg.ch
David Yermack

Stern School of Business

New York University

44 West Fourth Street, Suite 9-160

New York, NY 10012

and NBER

dyermack@stern.nyu.edu 


\section{Smokescreen: \\ How managers behave when they have something to hide}

\section{Introduction}

In most financial frauds, a company tries to make its performance appear better than it really is, hoping to achieve a valuation that wouldn't be supported by its true cash flows. This paper looks at the opposite case. We investigate the disclosure and governance practices of more than 200 U.S. companies accused by government authorities of participating in price-fixing cartels. These firms earn strong cash flows, and continuation of their schemes requires obfuscation of the windfalls from regulators, analysts, customers, and at times, even their own boards of directors.

Connor and Helmers (2007) define a cartel as "an association of legally independent firms that aims to raise their joint profits through explicit agreements. Hardcore cartels aim to control prices or restrict supply (or both)." Decisions to join cartels are typically taken by a firm's very top managers and then implemented by the intermediate management (Harrington, 2006). The role of top management suggests that corporate governance may affect formation and continuation of a cartel. For example, cartels may occur more readily in firms with a high concentration of power at the top level, a weak or inattentive board of directors, or strong pay-for-performance incentives 
(Spagnolo, 2005). ${ }^{1}$ In addition, financial reporting strategies that cause signal-jamming, such as earnings smoothing and suspicious accrual patterns, might be expected to occur frequently with cartels. Cartelists have an ongoing need to deter both cheating and the entry into the industry of new firms (Levenstein and Suslow, 2006). If a cartel member deviates from a collusive agreement, its sudden jump in earnings might be detected by co-conspirators, who could start a price war that could destroy the cartel. Therefore, we would expect cartels to use financial reporting strategies that obscure year-to-year swings in profitability.

This paper investigates how cartel firms attempt to cover up their conspiracies. We use an empirical framework similar to that of Kedia and Philippon (2009), who investigate cover-up actions by firms involved in fraudulent accounting. We study a sample of 1,569 firm-years from 218 U.S. companies participating in hard-core cartels between 1986 and 2010. We define a cartel firm-year as year in which the given cartelist has been involved in price fixing. The starting point and duration of the cartels in our sample are identified by enforcement actions brought by government antitrust authorities. We compare these cartel firm-year observations to observations from a set of control firms matched on size and industry. As in other empirical studies on cartels, our sample is subject to a selection bias as we are only able to consider discovered and indicted

\footnotetext{
${ }^{1}$ Theoretical research shows that cartel formation may be motivated not only by the potential profits from price-fixing, but also by management incentives (e.g., Levenstein and Suslow, 2006). Spagnolo (2005) adds managerial incentives schemes to a supergame-theoretic model of dynamic competition and shows that when managers have a preference for smooth time paths, collusion with other firms becomes more likely. This could be caused by management bonus contracts that have capped incentive provisions. His model shows that even though income smoothing is costly, shareholders tolerate the cost in return for the higher collusive profits. Buccirossi and Spagnolo (2008) show in a classical model of repeated oligopoly that the stability of tacit collusive agreements is positively correlated with performance-based incentives provided to top management.
} 
cartels, which are believed to represent only a minority of the price-fixing conspiracies that occur worldwide (see Connor, 2010).

We document a range of accounting and governance strategies that cartel firms adopt in systematic patterns, apparently with an eye toward prolonging their conspiracies and evading legal liability. To mislead readers of financial statements, companies engage in earnings smoothing and frequently reclassify the industrial segments for which they report line-of-business results. They file abnormally large numbers of financial restatements. In corporate governance, cartel firms favor outside directors who are likely to be inattentive monitors due to their status as foreign or "busy" (belonging to a large number of boards) and their low rates of meeting attendance. When directors resign, they are often not replaced, and new auditing firms are engaged significantly less often than expected. Since stability of the management team probably represents a necessary condition for continuing a conspiracy, cartel firms tend to promote CEOs from within, rather than hiring them from outside. They exhibit lower than expected rates of CEO replacement, controlling for performance, and feature abnormally large numbers of other managers who are chosen by the incumbent CEO. Cartel managers exercise their stock options faster than managers of other firms. We also find a pronounced pattern of political donations by cartel firms, as their political action committees (PACs) donate more frequently to political candidates and in larger amounts than firms in a matched control sample. While our results are based only upon firms engaged in price fixing, we expect that they should apply generally to all companies in which the managers seek to conceal poor performance or personal wrongdoing. 
As an example, the pharmaceutical company Bristol-Myers Squibb Co. is one of the more prominent firms in our sample. It was charged with participating in cartels in three different countries between 1999 and 2004. During this cartel period, BristolMyers engaged in many of the practices described in our analysis below. The company reclassified its line-of-business segments nearly every year, constantly reorganizing them into different subcategories and at one point eliminating them altogether for a two-year period. Five years of earnings results were restated, including two years that were restated twice. The company was sued twice during this period for securities fraud. It retained the same auditing firm for the entire cartel period despite the outward signs of financial reporting problems. Two new outside directors joined the Bristol-Myers board between 1998-2004. One fell into the "busy" category, with three or more board memberships, and the other was based in a foreign country. Five of the incumbent outside directors from the start of the cartel period also had busy status. Both CEOs who served during this period had been promoted internally. At the end of its cartel period in 2006, soon before it agreed to plead guilty to federal criminal charges arising from an antitrust investigation, Bristol-Myers appears to have undergone a governance and financial reporting overhaul. The CEO was replaced by an outside board member who had not previously worked for the company. The firm changed auditors, replacing PricewaterhouseCoopers with Deloitte \& Touche, and added a law-and-order independent outsider to its board, the former FBI Director and federal judge Louis Freeh.

The remainder of the paper is organized as follows. Section 2 describes the sample and variables. Section 3 reports the results from the empirical analysis. Section 4 concludes. 


\section{Sample selection}

\subsection{Cartel firms}

We use the U.S. firms included in an extended version of Connor's (2010) hand collected Private International Cartel dataset, which covers private cartels discovered, disclosed and sanctioned by regulators around the world between January 1986 and December $2010 .^{2}$ The dataset omits cartels protected by sovereignty or multilateral treaties, as well as those for which no sanctions were imposed within five years of the authorities' discovery. A total of 648 cartels involving 2,115 companies appear in the dataset, although in certain cases many more firms are sanctioned anonymously. Many companies are repeat offenders and participate in multiple cartels. The median cartel involves eight companies and lasts five years before discovery by regulators; the maximum values are considerably higher, with some cartels lasting for decades and involving dozens of companies or more. ${ }^{3}$

The dataset includes each firm's name, country of incorporation, the market(s) and continent(s) where collusion took place, the duration of the collusive agreement, and if known, the fines imposed, leniency granted by regulators, and estimated overcharges to consumers. Information is collected mainly from filings, documents, reports, and press releases from the antitrust authorities in different countries, as well as newspaper and magazine articles retrieved through search engines like Factiva or Lexis-Nexis. The sample generally includes more observations in recent years, with between 300 and 400

\footnotetext{
${ }^{2}$ The dataset in Connor (2010) covers the time period from January 1990 to December 2009.

${ }^{3}$ Connor (2010) reports one case of more than 2,000 unnamed construction companies accused of price fixing by authorities in the Netherlands.
} 
companies in each of the years 2005-2009. We do not know whether this pattern occurs due to better enforcement, more disclosure by regulators, more coverage by the press, or a greater tendency by companies to collude in price fixing or bid rigging, though Connor and Helmers (2007) estimate that only $10 \%$ to $30 \%$ of all price-fixing conspiracies are ever discovered. European companies comprise the majority of observations in the dataset, although many cartels are global in nature and involve multinational firms operating on several continents. Connor and Helmers (2007) estimate that by the early 2000s, worldwide corporate penalties for firms participating in cartels stabilized at or above $\$ 2$ billion per year, with approximately $60 \%$ due to government fines (mainly from U.S. and European regulators) and $40 \%$ paid to settle private litigation.

To select our sample, we begin with 819 U.S. companies included in the international dataset. We exclude all cartels which started before 1986 and all firms not covered by Compustat, which substantially reduces the sample size to 218 firms that are involved in a total of 185 conspiracies (certain conspiracies concern more than one sample company). We obtain data for 1,569 cartel company-year observations (including part-years) for these 218 firms over the 1986-2010 period, with 67 of the 218 companies participating in more than one cartel. The mean and median cartel period is six years for our sample, and the maximum value is 22 years for a marine hose cartel involving the rubber manufacturers Goodyear and Parker Hannifin. ExxonMobil is involved in 13 individual cartels, the most of any company in the sample, followed by Johnson \& Johnson with nine.

We augment the financial statement data from Compustat for our 218 firms with information from other financial and governance sources, including the Center for 
Research in Securities Prices (CRSP) stock price database, the RiskMetrics Governance and Directors databases, Standard and Poor's ExecuComp database, and the AuditAnalytics database. Missing values in these datasets reduce the observations available for some of our analysis below.

Figure 1 displays the mean and median return on assets (ROA) for our sample companies over a symmetric window of three years around the starting point of each cartel. ROA is calculated throughout the paper as the ratio of earnings before interest and taxes (EBIT) divided by total assets. Figure 1, which provides a reality check on the accuracy of regulators' identification of the cartels, shows that profitability decreases until the last year before a firm enters into a cartel, and then increases steadily over the subsequent four years, beginning in year 0 , the first cartel year. In our regression analysis below, we generally pool together the 1,569 cartel-firm observations with a much larger control sample of 12,041 observations described below, and we test the significance of an indicator variable for the cartel firm-year observations.

\subsection{Control sample of matched firms}

We construct a control sample of comparable companies matched on size and industry. For every cartelist, we identify the Compustat firms with the same two-digit primary SIC code in the year before the first collusive agreement starts. We then take the five firms with firm size, measured by total assets, closest to the size of the cartel firm. If a conspiracy was already active in 1986, the beginning of our sample period, we use the 
first cartel firm-year in our sample to form the corresponding control group. No cartel firm is permitted also to enter the control sample. ${ }^{4}$

Our final sample includes 1,569 cartel firm-years for 218 offending companies and a control group of 12,041 firm-years for 721 companies matched on size and industry. Table 1 presents summary statistics comparing the means and standard deviations across these two subsamples for all the variables used in our analysis below. The table shows that cartel firms are larger and more profitable than their counterparts in the control sample, and they also exhibit sharply higher rates of accounting problems such as restatements, securities fraud litigation, and discretionary accruals. Cartelists often are the largest firms in their industries, which seems logical since substantial market power would be required to fix prices successfully, but also creates an issue in attempting to construct an appropriate control sample. Due to this pattern, we include a measure of firm size, or board size where appropriate, in virtually all regressions.

Table 2 studies the growth of important financial variables for cartel firms compared to the control group. We use the methods in Kedia and Philippon's (2009) study of firms committing financial fraud, regressing the growth rates of different quantities against indicator variables that equal one for three periods that we label Before, During, and After. The Before variable equals 1 in the two years prior to initiation of a cartel, the During variable equals 1 while the cartel is active, and the After variable equals 1 for the two years subsequent to the cartel. For firms with multiple conspiracies

\footnotetext{
${ }^{4}$ We experiment with a number of alternative control samples and find that other matching procedures make little difference in the size and significance of the regression estimates reported in the paper. For example, we replicate our results following the approach used in Kedia and Philippon's (2009) study of financial fraud, creating a group of non-cartelists including all companies that operate in the same two-digit SIC industry and are located in the same total assets quintile of Compustat in the year before each collusive agreement starts. Although this procedure results in a much larger control sample of more than 50,000 company-year observations, it has little impact on our results.
} 
in the sample, we delete observations that represent "overlap" years, within two years after one cartel but also within two years before the start of another. ${ }^{5}$ In contrast to the remainder of the paper, we also follow Kedia and Philippon (2009) in the construction of the control sample. Specifically, for every cartelist, we create a group of non-cartelists including all companies that operate in the same two-digit SIC industry and are located in the same total assets quintile of Compustat in the year before each collusive agreement starts. This approach ensures that the mean value of the control group is based on a sufficiently large number of firms at the cost of having some size disparity between the cartel sample and control sample. We estimate ordinary least squares panel regressions in which the dependent variable equals the change in growth rates of variables such as sales, from which we subtract the mean change in growth rates for the same variable in the corresponding control group for each cartel firm. We winsorize all these relative growth variables to limits of -1 and 1 . We delete observations for which ROA exceeds 10 or is less than -10 . To control for the dependence of the disturbance terms, we calculate standard errors using the cluster-robust variant of the Huber-White sandwich estimator.

Results in Table 2 show that cartel firms thrive during the periods of their conspiracies, as estimates for the During variable indicate that sales grow $2.3 \%$ faster, return on assets grows $0.2 \%$ faster, and market capitalization rises $3.3 \%$ faster than the comparable growth rates for the control sample. These results are all significant at conventional levels. In contrast, profitability falls significantly faster than expected during the Before and After years, sales growth is slower than expected during the Before

\footnotetext{
${ }^{5}$ We relax this assumption by including these overlap years in both the Before and After samples, and also by counting the overlap years as cartel years. Neither of these changes has any discernable effect on the size and significance of the estimates reported in Table 2.
} 
years, and market capitalization falls faster than expected during the After years, reversing the shareholder gains from the cartel periods. Cartel firms seem to respond to their strong profits by hiring more workers and increasing their bases of fixed assets, as we also observe significant growth in both employment and property, plant and equipment. The bottom rows of the table report Wald $F$-tests for differences in coefficient estimates for each variable in the Before vs. During subperiods as well as During vs. After. The majority of these estimates are significant at conventional levels, and most of the others come close.

It is not clear why firms would systematically expand employment and fixed assets during the cartel period, especially since price-fixing strategies often involve restriction of output to maintain high prices. Many cartel firms agree either explicitly or implicitly not to encroach upon the market shares of rivals. These firms may expand to create a diversion for regulators, in line with many of the results found below, or they may use their cash flows to enter other lines of business as part of an empire building strategy, rather than returning the profits to stockholders. Expanding employment and assets may also represent a strategy to curry favor with regulators, who may tend to protect firms that add jobs and capital spending to the economy.

\section{Empirical results}

We study the behavior of cartel firms in two broad areas: corporate governance and financial reporting. Our analysis in each subsection below investigates a variety of strategies that these firms may use to evade scrutiny from internal and external monitors, including changes in board composition, selection of the management team, changes in 
auditors, and various financial reporting strategies such as restatements and earnings smoothing. We also investigate top managers' exercises of stock options and the frequency with which cartel firms become targets of class action shareholder litigation for securities fraud.

\subsection{Director turnover and replacement}

A company could participate in a cartel either with or without the knowledge of its board of directors, and for research purposes it may be difficult to predict which types of boards are more likely to be associated with collusive behavior. However, we can make more straightforward predictions about changes in the board. Companies should be reluctant to replace directors who resign or retire, because recruiting a new monitor from outside the company creates a risk of the cartel being exposed or halted.

Table 3 presents an analysis of board turnover and changes in board size for our cartel firms compared to companies in the control sample. We collect data on individual directors from the RiskMetrics database, and the limited coverage of this source causes a large reduction in our sample size. Our regressions include control variables for institutional investor ownership, board size, Tobin's $Q$, the growth rate of ROA, industry fixed effects, and year fixed effects. As an alternative specification, we drop the year fixed effects in columns 2 and 4 and instead use an indicator variable that equals one beginning in 2002, the first-year in which the Sarbanes-Oxley Act and other regulations required companies to begin implementing changes in board structure.

Table 3 shows two clear patterns. Directors resign or retire more frequently in cartel firms compared to companies in the control sample, and when they leave, cartel 
firms are more likely to allow the board to shrink rather than replacing them. Reasons for director resignations are not clear, but one possibility is that board members who become aware of wrongdoing leave quietly to evade future legal liability or to signal disagreement with management's actions (see Fahlenbrach, Low, and Stulz, 2012). The motive for cartel firms not to replace exiting directors seems more plain: by leaving a board seat vacant, the company avoids the possibility of being monitored by a new individual from outside the firm.

Table 4 analyzes the monitoring capacity of directors appointed to the boards of cartel firms compared to board appointees by companies in the control sample. We study directors in three categories: those who are busy, those who have poor attendance records, and those who reside in foreign countries. These types of directors have been shown in recent papers to perform poorly as monitors, due to such factors as distraction, distance, fatigue, and their unfamiliarity with U.S. accounting rules. Busy directors, defined as those serving on three or more boards simultaneously, are studied by Fich and Shivdasani (2006). Directors with attendance problems are those who miss more than $25 \%$ of the board and committee meetings in a given year. Foreign independent directors are the subject of a recent paper by Masulis, Wang, and Xie (2012), who kindly shared their sample with us for use in this study.

We estimate a Poisson maximum likelihood model of busy director appointments in column 1 of Table 4. In column 2, we study the appointment of directors with attendance problems, but we use a binary probit dependent variable instead of a Poisson count data model since there are almost no cases in which companies appoint more than one director with attendance problems in the same year. For the same reason, we 
continue using the probit framework in models of foreign director appointments in columns 3 and 4 of Table 4 . Estimates in Table 4 indicate that when appointing new directors, cartel firms are more likely to select outsiders in each of these three categories, consistent with a conjecture that management nominates new board members who are unlikely to monitor aggressively. The result for foreign directors continues to hold when we augment the regression with a control variable for the fraction of the firm's sales that occur outside the U.S., since foreign directors are expected to be more valuable in multinational firms.

\subsection{Management turnover and replacement}

Because most cartels are likely initiated by managers without the knowledge of the board of directors, we can make certain predictions about CEO selection and retention in companies involved in price fixing. Controlling for performance and other relevant factors, we expect cartel firms to exhibit less CEO turnover than other companies, since it should be risky for the CEO to recruit a successor and entrust that person with the continuation of a conspiracy. For similar reasons, when a new CEO is selected, we would expect that person to come from within the company rather than from outside.

Table 5 presents estimates from a probit model in which we study these relationships. In the first column, we model CEO replacement as a function of standard control variables such as firm size, growth, profitability, industry and year fixed effects, and an indicator for CEO ages 66 through 72, when many planned retirements take place. Estimates for this model have the expected signs and significance - for instance, CEO replacement occurs less often when a firm is growing and is profitable. The model also 
includes an indicator variable for cartel membership. As expected, it has a negative estimate and is statistically significant at the 10 percent level.

In the second and third columns we study whether a CEO is slected internally or externally. The model in the second column is restricted to those company-years (about $10.5 \%$ of the observations) in which a CEO turnover occurs. The model in the third column is a cross sectional study of whether the firm's current CEO was selected from inside the firm, regardless of his tenure in office. In both columns we obtain positive and significant estimates for the cartel firm indicator variable, consistent with these firms choosing their leaders from inside the company.

A line of recent papers begun by Landier et al. (2013) examines the role of the CEO in hand-picking his own management team. In our setting, we would expect cartel firms to have a relatively large fraction of top managers chosen personally by the CEO, since maintaining a price-fixing conspiracy should require close personal relationships among the company's leaders. We study the two measures of the fraction of top managers appointed to the executive board after the selection of the incumbent CEO. These measures, following definitions in Landier et al. (2013), rely on the tenure of the other top 5 managers included in the ExecuComp database. The FTAl variable used in regressions in the left two columns of Table 6 counts a manager as having been appointed by the current CEO if he has served strictly less time in office than the CEO. The FTA2 variable in the right two columns is less restrictive, counting a manager as having been chosen by the current CEO if both took office in the same year. The table presents Tobit estimates of these variables as a function of various CEO and company characteristics. Across all four models shown, we obtain a robust result that cartel firms have more top 
managers appointed by the incumbent CEO, after controlling for whether the CEO himself was chosen from inside the firm, the CEO's age, firm size, firm age, and other variables. Our findings are consistent with the idea that inside cartel firms, CEOs place a premium on personal relationships with other top managers, and are less likely to work with executives whose tenure predates theirs.

\section{3. $\quad$ Changes in auditors}

We investigate cartel firms' changes in auditors to explore whether a pattern exists similar to that for boards of directors, with management exhibiting reluctance to bring in new outsiders who might monitor aggressively and become aware of the firm's illegal conduct. We use Compustat to identify changes in auditors and create an indicator variable that equals one for years in which the database reports a different auditor than the previous year. We restrict the sample to observations in which firms have a Big 4 auditor and change from one Big 4 auditing firm to another. Only 22 observations, or less than $2 \%$, for the cartel firm sample are associated with smaller auditing firms, and the fraction is significantly higher for firms in the control sample. A limited number of auditing firms exit the industry due to mergers or liquidation (including, most famously, Arthur Andersen). In these cases, when an auditor change is mandatory and beyond the control of the firm, we set the auditor change indicator equal to missing.

Summary statistics in Table 1 indicate that auditor changes occur far less frequently for cartel firms than for companies in the control sample, with annual frequencies of $2.4 \%$ vs. $3.6 \%$, respectively. In Table 7 we report estimates for probit regressions in which the auditor change indicator is regressed against the cartel indicator 
as well as control variables for firm size, growth and profitability; these controls are used because larger firms are known to change auditors less often than smaller ones, and successful firms are also likely to change less often than unsuccessful ones for whom audit conflicts may occur with greater frequency. We include year fixed effects in the model on the left side of the table, and both year and industry fixed effects in the model shown on the right side.

Estimates for the cartel firm indicator confirm the results found in the simple comparison of sample means: cartel firms change auditors significantly less often than other companies, controlling for company size, performance, industry membership, and time period. The results are consistent with those found above documenting unusually slow replacement of directors and CEOs for cartel companies, and they suggest that management attempts to reduce external scrutiny by restricting access by new monitors.

\subsection{Contributions to political candidates}

We study contributions by the sample of cartel companies to U.S. federal political candidates, using Federal Election Commission data for annual donations by political action committees (PACs). We conjecture that the cartel firms will be unusually heavy donors, since political contributions may be viewed as a strategy for pre-empting future enforcement activity. Some basic descriptive statistics seem to bear out this hypothesis. Of the ten largest overall donors in the Federal Election Commission dataset, four are cartel firms in our sample, and eight of the ten largest one-year contribution totals come from cartel firms. As shown in the descriptive statistics in Table 2, cartel firms are more than twice as likely to be donors as firms in the control sample. 
In Table 8, we examine three dependent variables: the total dollar value of donations, if any, by each company's PAC each year; a binary $(0,1)$ indicator variable for whether a firm's PAC reports any political activity, and the "political index" of Cooper et al. (2010) based upon the number of candidates receiving donations from a company's PAC over the previous five years. ${ }^{6}$ As control variables, we include firm size (the log of assets), employees, Tobin's Q, leverage, and industry and year fixed effects.

Results in the table indicate that cartels are significantly more likely to donate, to donate larger amounts, and to donate to more candidates. These findings are consistent with the hypothesis that cartel firms actively support political candidates as part of a strategy of seeking future forbearance should the firm's behavior become a target of government regulators.

\subsection{Accounting restatements}

We investigate the propensity of cartel firms to engage in misleading financial reporting by analyzing their patterns of financial restatements. We use the Audit Analytics database to download information about restatements filed by all of our sample firms between 2000 and 2010. The database covers restatements filed electronically with the SEC since January 1, 2001, including restatements for past years filed since that date. We exclude years earlier than 2000, because the database's coverage of their entire restatement history is likely to be incomplete.

\footnotetext{
${ }^{6}$ Matching PAC donations with the sample companies is difficult, since some PACs use the names of corporate subsidiaries, and the Federal Election Commission does not provide an index number that can be matched with Compustat and other research databases. We are grateful to Jongsub Lee for providing a link table and assisting us with the data merge. A few companies report negative values for total political contributions in certain years as a result of donations that are returned; our results are robust to deleting these observations.
} 
Table 9 presents our regression analysis of restatements for cartel firms and the matched sample. In columns 1 and 2 , the dependent variable is a binary indicator for whether a fiscal year's results are eventually restated. These models are estimated in a probit framework, and column 2's specification includes industry and year fixed effects. In columns 3 and 4 , the dependent variable is the number of times that a given year's results are restated, with the models estimated in a Poisson maximum likelihood framework. Although the entire sample includes only 152 firm-years with more than one restatement, the analysis indicates a strong association between these cases and cartel participation. The control variables in all models follow those used by Larcker, Richardson, and Tuna (2007). They include the book-to-market ratio of common equity lagged one year, the log of the market value of equity lagged one year, a measure of external financing equal to net equity plus net debt issued deflated by the lagged market value of equity, acquisition spending over the lagged market value of equity, and a measure of free cash flow calculated as the difference of operating cash flow and average capital expenditure over the three prior years, deflated by lagged market value of equity. All control variables are winsorized at the $2^{\text {nd }}$ and $98^{\text {th }}$ percentiles.

Consistent with the summary statistics in Table 1 showing an almost $50 \%$ higher incidence of restatements among cartel firms, the estimates for the cartel firm indicator are positive and strongly significant in every column. The evidence shows that cartel firms are more likely to file restatements than firms in the control sample, consistent with a strategy of using misleading accounting in order to conceal the firm's true operating performance. As a robustness test, we re-estimate Table 9 with an alternative definition of the dependent variable: whether the firm restates any prior year's financials during the 
current year (left two columns), and the number of prior years' financials restated during the current year (right two columns). We obtain estimates quite similar to those shown in Table 9, with the cartel indicator variable always positive and significant.

\subsection{Earnings management}

We expect cartel firms to engage in abnormally high levels of accounting earnings management. This strategy might serve either of two purposes: it could conceal the firm's rising profits from regulators and analysts, and it may signal to competing firms a desire to promote stable profits in the industry. We begin by investigating whether cartels are unusually active in smoothing earnings. Our measure for earnings smoothing is based on the variability of the change in net income scaled by total assets (e.g., Leuz, Nanda, and Wysocki, 2003; Barth, Landsman, and Lang, 2008). A smaller variance of the change in net income is considered evidence of earnings smoothing.

As the change in net income is likely to be sensitive to various other factors, we use the variance of the residuals from a regression of the change in net income scaled by total assets on several explanatory variables identified in previous research as relevant controls for the change in net income (e.g., Lang, Raedy, and Wilson, 2006; Barth, Landsman, and Lang, 2008). We estimate the following pooled regression for a sample including all cartel and matched firm-years:

$$
\begin{aligned}
\Delta N I_{i t}= & \alpha_{0}+\alpha_{1} \operatorname{SIZE}_{i t}+\alpha_{2} \Delta G R O W T H_{i t}+\alpha_{3} \Delta E Q U I T Y_{i t}+\alpha_{4} L_{E V_{i t}}+\alpha_{5} \Delta \text { LIABILITY }_{i t} \\
& +\alpha_{6} \text { TURN }_{i t}+\alpha_{7} C F_{i t}+\alpha_{8} \Delta C F_{i t}+\varepsilon_{i t}
\end{aligned}
$$

where $\triangle N I$ is the change in net income scaled by total assets, SIZE is the natural logarithm of the market value of equity, $\triangle G R O W T H$ is the percentage change in sales, $\triangle E Q U I T Y$ is the percentage change in common equity, $L E V$ is total liabilities divided by 
book value of equity, $\triangle$ LIABILITY is the percentage change in total liabilities, TURN is sales over total assets, $C F$ is the annual net cash flow from operating activities divided by total assets, and $\triangle C F$ is the change in annual net cash flow from operating activities divided by total assets. The regression also includes year and industry fixed effects. Analysis in the left column of Table 10 is based on the residuals obtained from estimating this model. In the right column of Table 10, we repeat the analysis using a regression model augmented with interaction terms between all independent variables and an indicator variable that equals one for cartel firm-years. These interaction terms allow for different regression slopes for cartel firms and matched control firms, as the relation between the change in net income and the control variables may be affected by the cartel agreement itself.

To investigate earnings smoothing, we use a variance ratio test to compare the standard deviations of the residuals from regression (1), $\Delta N I^{*}$, between the observations for cartel firms and the observations for the sample of matched control firms. Although the test is commonly referred to as a "variance ratio test," the calculations are actually based on the ratio of the standard deviations of residuals in the relevant subsamples. This test design is valid provided that the mean level of the residuals does not significantly differ between cartel firms and control firms (Barth, Landsman, and Lang, 2008). As shown in Table 10, the mean residuals exhibit a statistically significant difference across the two groups for the simpler model in the left column, but the means are not significantly different for the richer model in the right column.

Although we focus on the results in the right column, both models in Table 10 indicate that the variance of the residuals, $\Delta N I^{*}$, is significantly lower for the 
observations for cartel firms compared to the observations for control firms. This is consistent with more earnings smoothing by cartels.

To understand firms' earnings smoothing more fully, we investigate two strategies for earnings management, the manipulation of discretionary accruals and deferred revenue. Our study of discretionary accruals follows the approach of Bergstresser and Philippon (2006) and Klein (2002). We estimate a firm's discretionary accruals with a version of the Jones (1991) and modified Jones (Dechow, Sloan, and Sweeney, 1995) models, which estimate nondiscretionary accruals as the fitted value from a regression. Discretionary accruals are then calculated as the residual difference of total accruals less nondiscretionary accruals.

Our methodology uses annual data from Compustat to calculate total accruals for firm $i$ in year $t$ as:

$$
T A_{i, t}=\frac{\left(\Delta C A_{i, t}-\Delta C L_{i, t}-\Delta C a s h_{i, t}+\Delta S T D_{i, t}-\operatorname{Dep}_{i, t}\right)}{A_{i, t-1}}
$$

where

$\triangle C A=$ the change in current assets

$\triangle C L=$ the change in current liabilities

$\Delta$ Cash $=$ the change in cash holdings

$\triangle S T D=$ the change in long term debt in current liabilities

$\Delta D e p=$ the depreciation and amortization expense of the firm

$\Delta A=$ firm size (in assets) 
We follow Klein (2002) by estimating expected accruals at the industry level by fitting the following regression each year across all Compustat firms in each two-digit SIC industry:

$$
T A_{i, t}=\alpha_{0}+\alpha_{1} * \frac{1}{A_{i, t-1}}+\alpha_{2} * \Delta \operatorname{Rev} v_{i, t}+\alpha_{3} * P P E_{i, t}+\varepsilon_{i, t}
$$

where $\triangle R e v$ is the change in sales and $P P E$ is gross property, plant and equipment, both deflated by lagged assets. We require a minimum of 12 observations per regression. Nondisicretionary accruals are then calculated for every firm-year observation as:

$$
N D A_{i, t}=\tilde{\alpha}_{0}+\tilde{\alpha}_{1} * \frac{1}{A_{i, t-1}}+\tilde{\alpha}_{2} * \Delta \operatorname{Rev} v_{i, t}+\tilde{\alpha}_{3} * P P E_{i, t}
$$

where $\tilde{\alpha}_{0}, \tilde{\alpha}_{1}, \tilde{\alpha}_{2}, \tilde{\alpha}_{3}$ are the estimated parameters from equation (3). This leads to the calculation of discretionary accruals:

$$
D A_{i, t}=T A_{i, t}-N D A_{i, t}
$$

As an alternative, we use the modified Jones model. Instead of deriving the fitted values used to calculate $N D A$ in equation (4) from the regression in equation (3), we estimate the following regression which substitutes the change in sales less the change in receivables for the change in sales, i.e.,

$$
T A_{i, t}=\alpha_{0}+\alpha_{1} * \frac{1}{A_{i, t-1}}+\alpha_{2} *\left(\Delta \operatorname{Re} v_{i, t}-\Delta \operatorname{Re} c_{i, t}\right)+\alpha_{3} * P P E_{i, t}+\varepsilon_{i, t}
$$

where $\Delta R e c$ is the change in receivables deflated by lagged assets.

In Table 11 we present least-squares estimates of discretionary accruals for our cartel firms and the control sample. Other explanatory variables, following Klein (2002) and Bergstresser and Philippon (2006), include firm size (the log of total assets), leverage, Tobin's Q, the absolute value of the change in return on assets, and the natural 
$\log$ of firm age (based on the company's first inclusion in the CRSP database). Both models include year and industry fixed effects. Estimates for the cartel firm indicator in the left two columns of Table 11 are both positive indicating that cartel firms are more aggressive about using accruals. However, only the coefficient in the first column when the Jones measure is the dependent variable is significant at the 5\% level. The coefficient for the Modified Jones measure in the second column is (borderline) insignificant.

In the third and fourth columns of Table 11, we change the dependent variable to equal the absolute value of discretionary accruals. This allows us to obtain a measure of cartel firms' accounting aggressiveness without reference to whether the accruals tend to increase or reduce reported earnings. As in the first two columns of the table, we again find strong evidence that cartel firms are more likely to avail themselves of accruals, whatever the direction of the impact on earnings.

Table 11 continues with two regressions estimating cartel firms' propensity to record deferred revenue, an accounting entry that essentially pushes profits into a future period by balancing an increase in cash received with an entry on the liability side of the balance sheet; the liability is then converted into shareholders' equity, an act that increases the firm's profits, during the future period when the income is deemed to be earned. We calculate deferred revenue as the sum of the Compustat variables DRC (revenue that has not been earned but is expected to be recognized in the current year) and DRLT (revenue that has not been earned and will be recognized in more than one year).

We present a Tobit analysis in column 5 of Table 11, with the dependent variable equal to deferred revenue scaled by net sales. In column 6 , we estimate a binary probit 
model in which the dependent variable equals one if the firm has positive deferred revenue on its balance sheet in that year. We use the same explanatory variables that appear in our models of discretionary accruals. For either model, the estimate for the cartel firm indicator is negative and significant. The result is quite similar to that found for discretionary accruals, implying that cartel firms tend to report higher earnings in current periods.

Interpreting the results in Table 11 seems challenging. Our main thesis in this paper is that cartel firms actively try to conceal the extent of their success in order to prolong the benefits from collusion. This might suggest less aggressive earnings management and slower revenue recognition, but we find the opposite. This may occur for a number of reasons. Cartel firms may be confident that profits will rise in the future and see little need for establishing accounting reserves and delaying revenue recognition. Alternatively, cartelists may feel vulnerable to outside scrutiny if revenue deferrals and slow accruals lead to an overwhelming delay of profit reporting, and they may make no effort to delay favorable accounting news in order to keep the pipeline clear of future positive news that could raise a red flag for regulators. Finally, cartel managers may be inherently unethical. They may inflate current-period earnings for reasons that are similar to, but not dependent upon, their tendency to engage in collusive behavior with rival firms.

\subsection{Segment reclassification}

Diversified companies are required to report line-of-business financial data in industry segments, providing information about key aggregates such as sales, operating 
profit, capital spending, and assets invested. However, companies have discretion to use their own judgment when setting the boundaries between their business entities. The financial statements of major conglomerates routinely exhibit year-to-year changes in the number and relative size of business segments. These could occur due to acquisitions and divestitures, changes in operating performance, or accounting decisions made by management. Regardless of the motivation for segment reclassifications, they tend to obscure the clarity of a firm's financial results by making year-over-year performance comparisons difficult.

We study the extent to which the cartel firms in our sample reclassify their industrial segments on a year-to-year basis, since these accounting adjustments represent a further strategy for concealing the firm's financial results from external audiences. For our cartel firms and the control sample, we study annual changes in the intra-firm Herfindahl Hirschman Index as a way to infer segment reclassifications. We construct the index for each firm-year using data from the Compustat Segments database. We use total assets as a measure of the size of each industrial segment. The Herfindahl Hirschman Index is computed as the sum of the squares of each segment's assets as a proportion of the square of total assets for the company. For example, if a firm has only one segment, its index equals 1.0 , and if it has 10 segments that each contribute $10 \%$ of its assets, its index equals 0.1. Hence, the index's value decreases as the degree of diversification increases.

In Table 12 we report results from regression estimations in which the dependent variable equals the absolute value of the annual change in the Herfindahl Hirschman Index. We use the absolute value because we are concerned only with whether cartel 
firms adjust the relative sizes of their reporting segments on a year-to-year basis, rather than whether they increase or decrease their degree of diversification. As control variables, the model includes a specification based on Berger and Ofek's (1995) study that uses segment financial data to calculate value losses from diversification, including the log of total assets, ROA (EBIT over total assets), and capital spending (CAPX over total assets). We also include intangible assets over total assets as a control variable. Year fixed effects are included in both columns of the table, and the second column also includes industry fixed effects. We use a Tobit specification since the absolute value of the dependent variable is left-censored at zero.

Results shown in Table 12 indicate that cartel firms change the distribution of assets across segments more than matched control firms, as the cartel indicator variable has a positive and significant estimate in both models. These estimates confirm our hypothesis that frequent segment reclassification helps these companies diminish the clarity of their performance by making more difficult year-over-year comparisons at the industry level. As a robustness check, we reestimate Table 12 after dropping observations for the year 1998, when the reporting standards changed for disclosure of segment results, causing a large number of companies to reclassify their businesses. Deleting the 1998 observations has very little impact on the results.

\subsection{Mangers' exercise of stock options}

In Kedia and Philippon's (2009) study of companies that commit financial fraud, the authors document an abnormally rapid exercise of in-the-money stock options by those firms' managers. The obvious interpretation of their results is that managers 
attempt to withdraw equity compensation from the company when the per-share price is inflated above its likely long-term value. We investigate stock option exercises by cartel firms. If these managers also exercise stock options rapidly, the motivation may be more subtle than for executives in companies that commit fraud. A successful cartel may expect its stock price to rise over time, suggesting that the managers would be patient about withdrawing equity compensation. However, they may have concerns about whether the cartel can be sustained, and they may wish to withdraw their compensation before regulators discover the scheme; this would accord with our estimates in Table 2, showing that cartel firms rise quickly in value during the cartel period but fall very quickly after the cartel ends. In addition, rapid stock option exercises may play a diversionary role, by communicating to outsiders that the managers do not expect future abnormal increases in the stock. It may also serve as a communication device by sending signals to managers of other firms in the cartel.

In Table 13 we present an analysis of stock option exercises by the CEO and the top five managers in our cartel firms and our control sample. Our data source for option exercises is the $\mathrm{S} \& \mathrm{P}$ ExecuComp database, and relying on this database greatly reduces our sample size since it covers only about one-quarter of the companies on Compustat. Our regressions follow those reported by Kedia and Philippon (2009). We use two dependent variables: (i) the dollar value of option profits realized by managers, divided by the total amount by which options are in-the-money (their intrinsic value) at the start of the year, and (ii) a more simple calculation of the ratio between number of options exercised and the number that are vested and could theoretically have been exercised, whether in-the-money or not. Control variables include the size of the firm's total 
inventory of outstanding employee stock options, the exercise rate for all firms in the two-digit SIC industry, Tobin's $Q$, and the firm's stock return in the past year, along with fixed effects for year and industry.

Results of these estimations appear in Table 13. In every model estimates indicate that managers from cartel firms exercise their stock options more rapidly than managers from firms in the control sample, although the estimate in the right column is not statistically significant. As noted above, these patterns of early option exercise could occur for a number of reasons, but they are consistent with an interpretation that managers wish to withdraw their equity compensation before some future date at which the cartel might be exposed and the firm's stock price could drop.

We investigate other forms of executive compensation to see whether the managers of cartel firms benefit from other strategies in additional to their early liquidation of stock-based compensation. For instance, the strong cash flows and earnings smoothing exhibited by cartel firms may help their managers obtain higher cash bonuses. However, we find little evidence of other patterns of abnormal compensation in these companies. The overall level of CEO pay, the strength of pay-performance sensitivity, and the fraction of top management pay attributable to the CEO is not significantly different in cartel firms compared to companies in the control sample.

\subsection{Securities fraud litigation}

We use the Stanford Law School Securities Class Action database to identify companies accused of financial fraud in class action civil litigation brought by shareholders. Ultimately 45 of our 218 cartel firms are sued for securities fraud one or 
more times (for a total of 61 fraud firm-years) during the sample period, which does not begin until 1996, the starting date of the Stanford database. When scaled by the number of observations in the sample, the lawsuit frequency for the cartel firms exceeds 5 percent per year, almost three times higher than the frequency for companies in the control sample, as shown by the sample means reported in Table 1 .

In Table 14 we present regression analysis of the incidence of securities fraud lawsuits. A binary probit model appears in the left column, with the dependent variable equal to one if the firm is sued in a given year. A Poisson maximum likelihood model in the right column is based on the number of lawsuits filed per year. As in our other regressions, control variables include firm size, ROA, and fixed effects for years and industries. We obtain strongly positive and significant estimates for the cartel indicator variable, confirming the result that these firms attract shareholder litigation for fraud at unusually high frequencies.

We reviewed many of the cases in the Stanford database and found that price fixing is rarely, if ever, the basis of shareholders' complaints. Cartel membership is not by itself an act of fraud, and shareholders may have difficulty arguing that they sustain damages when a firm successfully conspires to fix prices. Instead, the shareholder litigation may be a byproduct of the other signal-jamming strategies related to financial reporting that are illuminated by the regression results above, such as frequent earnings restatements, segment reclassifications, or abnormally high discretionary accruals.

\section{Conclusions}


We study the behavior of 218 U.S. public companies that are accused by governments of illegal cartel activity. We find that the sample firms engage in a range of practices designed to obscure their behavior from both internal and external audiences. Compared to a control sample of firms with similar size and in the same industries, cartel firms appear to avoid new outside monitoring by not replacing board members who resign and changing auditors infrequently. When new directors are appointed to cartel firms, they tend to be busy or foreign-based directors who are known to be inferior monitors. Management teams are very stable and insular, exhibiting low CEO turnover, internal promotion of new CEOs, and recruitment of much of the management team by the incumbent CEO. In financial reporting, cartel firms engage in unusually high levels of earnings smoothing and file high numbers of financial restatements for the cartel years. They also frequently reclassify their industrial segments year-to-year when reporting lineof-business data in annual financial statements, making annual comparisons of financial results more difficult. Top managers of cartel firms exercise stock options more frequently than executives in the control sample, perhaps attempting to withdraw their equity compensation before the cartel is exposed and the firm's stock price falls. Cartel firms are also sued at high rates for securities fraud, although this litigation is rarely connected to the price-fixing activity itself. Finally, cartel firms make large and frequent donations to candidates for federal political office, perhaps as part of a strategy to induce regulatory forbearance.

We believe our results create a template for understanding how companies behave when they wish to conceal aspects of their financial performance. The firms in our sample engage in a range of signal-jamming strategies when preparing their annual 
financial statements, and they appear to avoid inviting scrutiny from new directors, new auditors, or new CEOs hired from outside. Managers try to cash out their performancebased compensation earlier than would be expected. Multiple explanations may apply to some of our results. For example, earnings smoothing or a certain timing of the exercise of stock options may be a communication device to other firms in a cartel.

Our results may extend to other situations, both benign and malign, in which companies actively try to conceal information from their own monitors and from outside audiences. Firms may not want to give clear pictures of their capital investment or new product development spending, for instance, and may seek to obscure unusual spending patterns through strategies such as segment reclassification or earnings smoothing. More concerning would be cases in which managers scheme to embezzle funds or mislead creditors about the firm's financial health. By understanding the playbook of strategies outlined in this paper, these and other problems might become apparent earlier to shareholders, analysts, and regulators. 


\section{References}

Barth, M.E., Landsman, W.R., and M.H. Lang, 2008, International accounting standards and accounting quality, Journal of Accounting Research 46, 467-498.

Berger, P.G., and E. Ofek, 1995, Diversification's effect on firm value, Journal of Financial Economics 37, 39-65.

Bergstresser D., and T. Philippon, 2006, CEO incentives and earnings management, Journal of Financial Economics 80, 511-529.

Buccirossi, P., and G. Spagnolo, 2008, Corporate governance and collusive behavior in Collins, W.D., ed., Issues in Competition Law and Policy 1, American Bar Association.

Connor, J.M., 2001, “Our customers are our enemies:” The lysine cartel of 1992-1995. Review of Industrial Organization 18, 5-21.

Connor, J.M., 2010, Recidivism revealed: Private international cartels 1990-2009.

Competition Policy Journal 6, 101-127.

Connor, J.M., and C.G. Helmers, 2007, Statistics on modern private international cartels, 1990-2005. Unpublished manuscript, Purdue University.

Cooper, M.J., Gulen, H., and A.V. Ovtchinnikov, 2010, Corporate political contributions and stock returns. Journal of Finance 65, 687-724.

Dechow, P., Sloan, R., and A. Sweeney, 1995, Detecting earnings management. Accounting Review 170, 193-225.

Fahlenbrach, R., Low, A., and R. Stulz, 2012, The dark side of outside directors: Do they quit ahead of trouble? Unpublished manuscript, Ohio State University.

Fich, E.M., and A. Shivdasani, 2006, Are busy boards effective monitors? Journal of Finance 61, 689-724.

Harrington, J.E., 2006, How do cartels operate? Foundations and Trends in Microeconomics 2, 1-105.

Jones, J., 1991, Earnings management during import relief investigations. Journal of Accounting Research 29, 193-228.

Kedia, S., and T. Philippon, 2009, The economics of fraudulent accounting. Review of Financial Studies 22, 2169-2199.

Klein, A., 2002, Audit committee, board of director characteristics, and earnings management. Journal of Accounting and Economics 33, 375-400. 
Landier, A., Sauvagnt, J., Sraer, D., and D. Thesmar, 2013, Bottom-up corporate governance, Review of Finance 17, 161-201.

Lang, M., Raedy, J.S., and W. Wilson, 2006, Earnings management and cross listing: Are reconciled earnings comparable to US earnings?, Journal of Accounting and Economics $42,255-283$.

Larcker, D.F., Richardson, S.A., and I. Tuna, 2007, Corporate governance, accounting outcomes, and organizational performance. Accounting Review 82, 963-1008.

Leuz, C., Nanda, D., and P.D. Wysocki, 2003, Earnings management and investor protection: An international comparison, Journal of Financial Economics 69, 505-527.

Levenstein M.C., and V.Y. Suslow, 2006, What determined cartel success? Journal of Economic Literature 44, 43-95.

Masulis, R.W., Wang, C., and F. Xie, 2012, Globalizing the boardroom - The effects of foreign directors on corporate governance and firm performance. Journal of Accounting and Economics 53, 527-554.

Spagnolo, G., 2005, Managerial incentives and collusive behavior. European Economic Review 49, 1501-1523. 
Table 1

The table shows descriptive statistics for a sample of 1,569 annual observations for 218 cartel participants and a control sample of 12,041 observations for 721 Compustat control firms matched on size and industry. Cartel firms are identified from the dataset of Connor (2010). Board of directors data is tabulated from the RiskMetrics Directors database, and busy independent directors are those serving on three of more boards. Foreign independent directors are identified from the sample of Masulis, Wang, and Xie (2012). The fraction of executives appointed by the current CEO is calculated following Landier et al. (2013). The political index is calculated according to Cooper et al. (2010). Financial statement data is obtained from Compustat, which is also used to identify auditor changes. Stock option exercise data is obtained from ExecuComp, securities fraud lawsuits are tabulated from the Stanford securities clearinghouse website, and financial restatements are reported on the Audit Analytics database.

Variable

Board becomes smaller (indicator)

Fraction of directors leaving the board

Newly appointed directors that are busy

Newly appointed directors with attendance problems

Newly appointed directors that are foreign and independent

Auditor change (indicator)

Value realized / intrinsic value of exercisable options (CEO)

Option exercised / exercisable options (CEO)

Value realized / intrinsic value of exercisable options (top 5 executives)

Option exercised / exercisable options (top5 executives)

Restatement filed for current year (indicator)

Number of restatements for current year

Discretionary accruals (Jones)

Discretionary accruals (Modified Jones)

Absolute discretionary accruals (Jones)

Absolute discretionary accruals (Modified Jones)

Deferred revenues

Deferred revenue dummy

Change in Herfindahl Hirschman Index

Securities fraud lawsuit for current year (indicator)

Number of securities fraud lawsuits for current year

Fraction of top executives picked by current CEO (FTA1)

Fraction of top executives picked by current CEO (FTA2)

CEO promoted from inside firm (indicator)

CEO turnover in current year (indicator)
Cartel firms

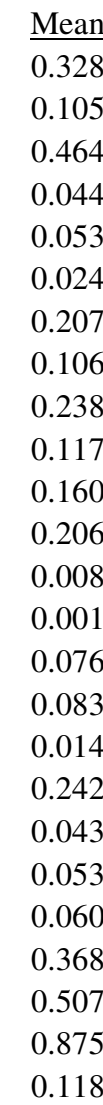

Control sample

\begin{tabular}{rrrrrr} 
Std.Dev. & Obs. & $\underline{\text { Mean }}$ & $\underline{\text { Std.Dev. }}$ & $\underline{\text { Obs. }}$ & $\underline{\underline{\text { Difference }}}$ \\
\hline 0.470 & 723 & 0.261 & 0.439 & 2,798 & $0.067^{\mathbf{a}}$ \\
0.105 & 769 & 0.090 & 0.107 & 2,846 & $0.014^{\mathbf{a}}$ \\
0.742 & 425 & 0.353 & 0.599 & 1,488 & $0.110^{\mathbf{a}}$ \\
0.207 & 180 & 0.020 & 0.139 & 657 & $0.025^{\mathbf{c}}$ \\
0.224 & 380 & 0.031 & 0.174 & 1,148 & $0.021^{\mathbf{c}}$ \\
0.154 & 1,445 & 0.036 & 0.186 & 10,225 & $-0.012^{\mathbf{b}}$ \\
0.294 & 748 & 0.173 & 0.276 & 3,137 & $0.034^{\mathbf{a}}$ \\
0.191 & 846 & 0.108 & 0.207 & 3,519 & -0.002 \\
0.267 & 808 & 0.220 & 0.261 & 3,465 & $0.018^{\mathbf{c}}$ \\
0.156 & 864 & 0.131 & 0.188 & 3,722 & $-0.014^{\mathbf{c}}$ \\
0.367 & 906 & 0.116 & 0.320 & 4,737 & $0.044^{\mathbf{a}}$ \\
0.518 & 906 & 0.138 & 0.418 & 4,737 & $0.068^{\mathbf{a}}$ \\
0.138 & 1,290 & -0.001 & 0.140 & 9,412 & $0.010^{\mathbf{b}}$ \\
0.158 & 1,290 & -0.004 & 0.152 & 9,404 & $0.005^{2}$ \\
0.115 & 1,290 & 0.078 & 0.116 & 9,412 & -0.002 \\
0.134 & 1,290 & 0.082 & 0.128 & 9,404 & 0.000 \\
0.055 & 690 & 0.034 & 0.133 & 3,587 & $-0.020^{\mathbf{a}}$ \\
0.429 & 690 & 0.348 & 0.476 & 3,587 & $-0.106^{\mathbf{a}}$ \\
0.101 & 1,008 & 0.036 & 0.089 & 8,014 & $0.007^{\mathbf{b}}$ \\
0.224 & 1,155 & 0.018 & 0.133 & 7,061 & $0.035^{\mathbf{a}}$ \\
0.268 & 1,155 & 0.018 & 0.136 & 7,061 & $0.042^{\mathbf{a}}$ \\
0.323 & 659 & 0.331 & 0.307 & 2,747 & $0.037^{\mathbf{a}}$ \\
0.318 & 659 & 0.472 & 0.303 & 2,747 & $0.035^{\mathbf{a}}$ \\
0.332 & 128 & 0.780 & 0.414 & 592 & $0.095^{\mathbf{b}}$ \\
0.323 & 1,076 & 0.123 & 0.329 & 4,792 & $-0.005^{2}$
\end{tabular}


Board size

Fraction of board that is independent

Fraction of shares held by institutional investors

Total assets (\$ millions)

Growth in total assets, prior three years

Market capitalization (\$ millions)

Sales (\$ millions)

Foreign sales (\$ millions)

Growth in sales, prior three years

Return on assets

Growth in return on assets, prior three years

Book-to-market ratio

Tobin's Q

Leverage

Options outstanding

Return to shareholders

External financing (indicator)

Acquisitions / market capitalization

Free cash flow

Firm age in years

Absolute value of change in EBIT

Capital expenditures / total assets

Intangible assets / total assets

CEO tenure with firm, based on ExecuComp appearances

Mean executive tenure with firm

CEO age in years

CEO tenure in years

Fraction of top executives picked in the CEO's first year

Number of business segments reported in financial statements

CEO aged between $66 \& 72$, prior year (indicator)

Annual spending by political action committees ( $\$$ millions)

Indicator for nonzero spending by political action committees

Political index

Change in growth rate of market capitalization

$\begin{array}{rrrrrrr}11.263 & 2.936 & 803 & 10.261 & 2.682 & 3,188 & 1.002^{\mathbf{a}} \\ 0.708 & 0.160 & 723 & 0.695 & 0.183 & 2,798 & 0.013^{\mathbf{c}} \\ 0.616 & 0.205 & 1,274 & 0.527 & 0.287 & 7,723 & 0.089^{\mathbf{a}} \\ 62,270 & 192,205 & 1,568 & 17,487 & 75,424 & 11,856 & 44,783^{\mathbf{a}} \\ 0.283 & 1.149 & 1,483 & 0.513 & 7.171 & 10,461 & -0.230 \\ 27,568 & 55,965 & 1,473 & 6,321 & 18,778 & 10,644 & 21,247^{\mathbf{a}} \\ 19,183 & 37,452 & 1,565 & 5,059 & 9,693 & 11,824 & 14,124^{\mathbf{a}} \\ 0.311 & 0.236 & 1,379 & 0.233 & 0.268 & 8974 & 0.078^{\mathbf{a}} \\ 0.215 & 0.513 & 1,478 & 0.638 & 14.583 & 10,396 & -0.423 \\ 0.095 & 0.081 & 1,563 & 0.076 & 0.128 & 11,746 & 0.019^{\mathbf{a}} \\ -0.041 & 5.287 & 1,477 & -1.891 & 157.269 & 10,355 & 1.851 \\ 0.492 & 0.523 & 1,473 & 0.549 & 0.665 & 10,610 & -0.057^{\mathbf{a}} \\ 1.864 & 1.350 & 1,475 & 1.788 & 1.542 & 10,617 & 0.077^{\mathbf{c}} \\ 0.669 & 0.216 & 1,559 & 0.643 & 0.297 & 11,828 & 0.026^{\mathbf{a}} \\ 55.670 & 101.537 & 954 & 24.014 & 88.017 & 4,595 & 31.660^{\mathbf{a}} \\ 1.642 & 56.081 & 1,436 & 0.737 & 28.922 & 10,056 & 0.905 \\ 0.015 & 0.271 & 820 & 0.004 & 0.278 & 4,512 & 0.011^{\mathbf{a}} \\ 0.028 & 0.073 & 1,270 & 0.035 & 0.088 & 9,219 & -0.007^{\mathbf{a}} \\ 0.019 & 0.255 & 1,301 & 0.016 & 0.263 & 8,334 & 0.003 \\ 35.684 & 24.666 & 1,369 & 23.081 & 20.383 & 8,712 & 12.600^{\mathbf{a}} \\ 1.026 & 9.155 & 1,519 & 1.565 & 36.223 & 11,065 & -0.539 \\ 0.051 & 0.040 & 1,520 & 0.060 & 0.067 & 11,492 & -0.009^{\mathbf{a}} \\ 0.130 & 0.155 & 1,423 & 0.117 & 0.169 & 10,482 & 0.013^{\mathbf{a}} \\ 4.123 & 2.787 & 668 & 3.970 & 2.789 & 2,809 & 0.153 \\ 4.710 & 1.794 & 668 & 4.801 & 1.964 & 2,804 & -0.092 \\ 57.359 & 6.835 & 1,136 & 56.187 & 7.258 & 5,139 & 1.172^{\mathbf{a}} \\ 6.373 & 6.710 & 1,095 & 6.378 & 7.126 & 4,802 & -0.005 \\ 0.175 & 0.193 & 668 & 0.168 & 0.183 & 2,809 & 0.008 \\ 2.769 & 1.759 & 1,197 & 2.155 & 1.458 & 9,520 & 0.614^{\mathbf{a}} \\ 0.049 & 0.216 & 1,139 & 0.048 & 0.215 & 5,180 & 0.001^{\mathbf{a}} \\ 70.3 & 160.0 & 1,569 & 16.6 & 70.1 & 12,041 & 53.7^{\mathbf{a}} \\ 0.494 & 0.500 & 1,569 & 0.228 & 0.419 & 12,041 & 0.266^{\mathbf{a}} \\ 101.0 & 143.2 & 1,569 & 28.0 & 74.5 & 12,041 & 73.0^{\mathbf{a}} \\ 0.033 & 0.337 & 1,262 & & & & \end{array}$


Change in growth rate of sales

0.023

0.015

0.032

Change in growth rate of property, plant and equipment

1,357

0.002

$0.171 \quad 1,275$

$0.204 \quad 1,325$

Significant at $1 \%$ (a), $5 \%$ (b) and $10 \%$ (c) levels.

$0.064 \quad 1,357$ 


\section{Table 2}

\section{Growth dynamics for cartel firms and matched sample}

The table reports OLS regression results of adjusted growth dynamics for a variety of financial and employment data. The sample includes 218 U.S. firms identified by regulators as cartel participants between 1986-2010. Each dependent variable in Columns 1-4 is a growth rate (one year log differences) relative to the mean growth rate of a control group of Compustat firms matched on size and industry, and in Column 5, the dependent variable is the one-year difference in return on assets (ROA) relative to the mean first difference of ROA for the control group. The indicator variable Before equals 1 for the two years preceding each cartel, During equals 1 during the cartel period, and After equals 1 for the two years after the cartel ends. $t$-statistics in parentheses are based on the cluster-robust variant of the Huber-White sandwich estimator. The table reports $p$-values of Wald tests for the hypotheses that $\beta_{\text {During }}$ equals $\beta_{\text {Before }}$ and $\beta_{\text {During }}$ equals $\beta_{\text {After }}$.

\begin{tabular}{|c|c|c|c|c|c|}
\hline $\begin{array}{l}\text { Dependent variables } \\
\text { (annual growth rates): }\end{array}$ & $\begin{array}{c}\text { Market } \\
\text { value }\end{array}$ & Sales & Employment & $\begin{array}{l}\text { Property, } \\
\text { plant and } \\
\text { equipment }\end{array}$ & $\begin{array}{r}\text { Return on } \\
\text { assets }\end{array}$ \\
\hline $\begin{array}{l}\text { Before } \\
\text { (indicator for two years prior to cartel) }\end{array}$ & $\begin{array}{r}0.006 \\
(0.274)\end{array}$ & $\begin{array}{l}-0.032^{a} \\
(-3.000)\end{array}$ & $\begin{array}{r}-0.003 \\
(0.301)\end{array}$ & $\begin{array}{r}-0.013 \\
(-0.963)\end{array}$ & $\begin{array}{l}-0.006^{\mathrm{c}} \\
(-1.696)\end{array}$ \\
\hline $\begin{array}{l}\text { During } \\
\text { (indicator for years in cartel period) }\end{array}$ & $\begin{array}{l}0.033^{\mathrm{a}} \\
(3.727)\end{array}$ & $\begin{array}{l}0.023^{\mathrm{a}} \\
(4.162)\end{array}$ & $\begin{array}{l}0.015^{\mathrm{a}} \\
(2.939)\end{array}$ & $\begin{array}{l}0.032^{\mathrm{a}} \\
(4.786)\end{array}$ & $\begin{array}{l}0.002^{\mathrm{c}} \\
(1.966)\end{array}$ \\
\hline $\begin{array}{l}\text { After } \\
\text { (indicator for two years following } \\
\text { cartel) }\end{array}$ & $\begin{array}{l}-0.035^{\mathbf{b}} \\
(-2.032)\end{array}$ & $\begin{array}{r}-0.016 \\
(-1.364)\end{array}$ & $\begin{array}{r}-0.002 \\
(-0.201)\end{array}$ & $\begin{array}{r}-0.007 \\
(-0.551)\end{array}$ & $\begin{array}{l}-0.010^{b} \\
(-2.416)\end{array}$ \\
\hline $\begin{array}{l}\text { Observations } \\
r \text {-squared }\end{array}$ & $\begin{array}{l}1,895 \\
0.008\end{array}$ & $\begin{array}{l}2,036 \\
0.018\end{array}$ & $\begin{array}{l}1,907 \\
0.005\end{array}$ & $\begin{array}{l}1,985 \\
0.017\end{array}$ & $\begin{array}{l}2,041 \\
0.006\end{array}$ \\
\hline $\begin{array}{l}\text { Wald test: } \beta_{\text {During }}=\beta_{\text {Before }} \\
\text { Wald test: } \beta_{\text {During }}=\beta_{\text {After }}\end{array}$ & $\begin{array}{r}0.199 \\
0.001^{\mathrm{a}}\end{array}$ & $\begin{array}{l}0.000^{\mathrm{a}} \\
0.003^{\mathrm{a}}\end{array}$ & $\begin{array}{r}0.094^{\mathrm{c}} \\
0.142\end{array}$ & $\begin{array}{l}0.001^{\mathrm{a}} \\
0.005^{\mathrm{a}}\end{array}$ & $\begin{array}{l}0.029^{b} \\
0.004^{\mathrm{a}}\end{array}$ \\
\hline
\end{tabular}

Significant at $1 \%(\mathbf{a}), 5 \%(\mathbf{b})$ and $10 \%(\mathbf{c})$ levels. 


\section{Table 3}

\section{Retention and replacement of directors}

The first two columns reports results from probit regressions in which the dependent variable equals 1 if board size decreases in a given year. The right two columns report the results from Tobit regressions of the percentage of directors leaving the board in a given year. The sample includes 218 U.S. firms identified by regulators as cartel participants between 1986-2010, as well as a control sample of Compustat firms matched on size and industry. $\ln$ (board size) is the natural log of the number of directors on the board. Board of directors data is obtained from the RiskMetrics Directors database. Tobin's $Q$ is defined as total assets minus the book value of equity plus the market value of equity over total assets. Past growth in return on assets (ROA) is the three-year growth rate in return on assets. SOX is an indicator variable which equals for the years after enactment of the Sarbanes-Oxley Act (2002 and after). $z$-statistics and $t$-statistics appear in parentheses.

\begin{tabular}{|c|c|c|c|c|}
\hline Dependent variable: & \multicolumn{2}{|c|}{$\begin{array}{l}\text { Board becomes smaller } \\
\text { (Probit) }\end{array}$} & \multicolumn{2}{|c|}{$\begin{array}{l}\text { Percentage of directors } \\
\text { leaving (Tobit) }\end{array}$} \\
\hline Cartel firm indicator & $\begin{array}{l}0.205^{\mathrm{a}} \\
(3.502)\end{array}$ & $\begin{array}{l}0.221^{\mathrm{a}} \\
(3.860)\end{array}$ & $\begin{array}{l}0.015^{\mathbf{b}} \\
(2.117)\end{array}$ & $\begin{array}{l}0.022^{\mathrm{a}} \\
(3.052)\end{array}$ \\
\hline$\%$ Institutional ownership & $\begin{array}{r}-0.204 \\
(-1.476)\end{array}$ & $\begin{array}{l}-0.264^{\mathbf{b}} \\
(-1.985)\end{array}$ & $\begin{array}{r}0.012 \\
(0.701)\end{array}$ & $\begin{array}{r}-0.002 \\
(-0.103)\end{array}$ \\
\hline $\ln ($ board size $)$ & $\begin{array}{l}-0.273^{a} \\
(-2.764)\end{array}$ & $\begin{array}{l}-0.292^{a} \\
(-2.986)\end{array}$ & $\begin{array}{r}0.126^{\mathbf{a}} \\
(10.191)\end{array}$ & $\begin{array}{l}0.120^{\mathrm{a}} \\
(9.674)\end{array}$ \\
\hline Tobin's $Q$ & $\begin{array}{l}-0.045^{a} \\
(-2.750)\end{array}$ & $\begin{array}{l}-0.045^{a} \\
(-2.767)\end{array}$ & $\begin{array}{l}-0.009^{a} \\
(-4.527)\end{array}$ & $\begin{array}{l}-0.009^{\mathrm{a}} \\
(-4.253)\end{array}$ \\
\hline Past growth in ROA x $10^{-2}$ & $\begin{array}{l}1.225^{\mathbf{b}} \\
(2.134)\end{array}$ & $\begin{array}{l}1.201^{\mathbf{b}} \\
(2.157)\end{array}$ & $\begin{array}{r}-0.097 \\
(-1.502)\end{array}$ & $\begin{array}{r}-0.088 \\
(1.374)\end{array}$ \\
\hline SOX & & $\begin{array}{r}-0.068 \\
(-1.345)\end{array}$ & & $\begin{array}{r}-0.008 \\
(-1.230)\end{array}$ \\
\hline Year fixed effects & Yes & No & Yes & No \\
\hline Industry fixed effects & Yes & Yes & Yes & Yes \\
\hline Observations & 3,354 & 3,354 & 10,046 & 10,046 \\
\hline Pseudo $r$-squared & 0.020 & 0.026 & & \\
\hline LR Chi-squared & & & $235.65^{\mathrm{a}}$ & $172.30^{\mathrm{a}}$ \\
\hline Prob $>$ Chi-squared & & & 0.000 & 0.000 \\
\hline
\end{tabular}

Significant at $1 \%(\mathbf{a}), 5 \%(\mathbf{b})$ and $10 \%$ (c) levels. 


\section{Table 4}

\section{Characteristics of new outside directors}

The table shows Poisson and probit regression estimates of models of the probability that new outside board members have certain characteristics. While the dependent variable is a count variable, it has too little variation to justify the estimation of Poisson models in columns 2 to 4 (in only two cases more than one director with attendance problems is appointed and in 4 cases more than one foreign independent director). The sample includes all new outside board appointments by 218 U.S. firms identified by regulators between 1986-2010 as cartel participants, as well as a control sample of Compustat firms matched on size and industry. Observations are restricted to the firms and period covered by the RiskMetrics Directors database (1996-present). Busy directors are defined as those holding three or more board seats. Directors with attendance problems are those who attend fewer than $75 \%$ of all board and committee meetings. The observations for attendance problems are stopped after 2001, when the Sarbanes-Oxley Act took effect and director attendance improved markedly. Data on foreign outside directors is obtained from Masulis et. al (2012). $\ln$ (board size) is the natural log of the number of directors on the board. $t$-statistics appear in parentheses.

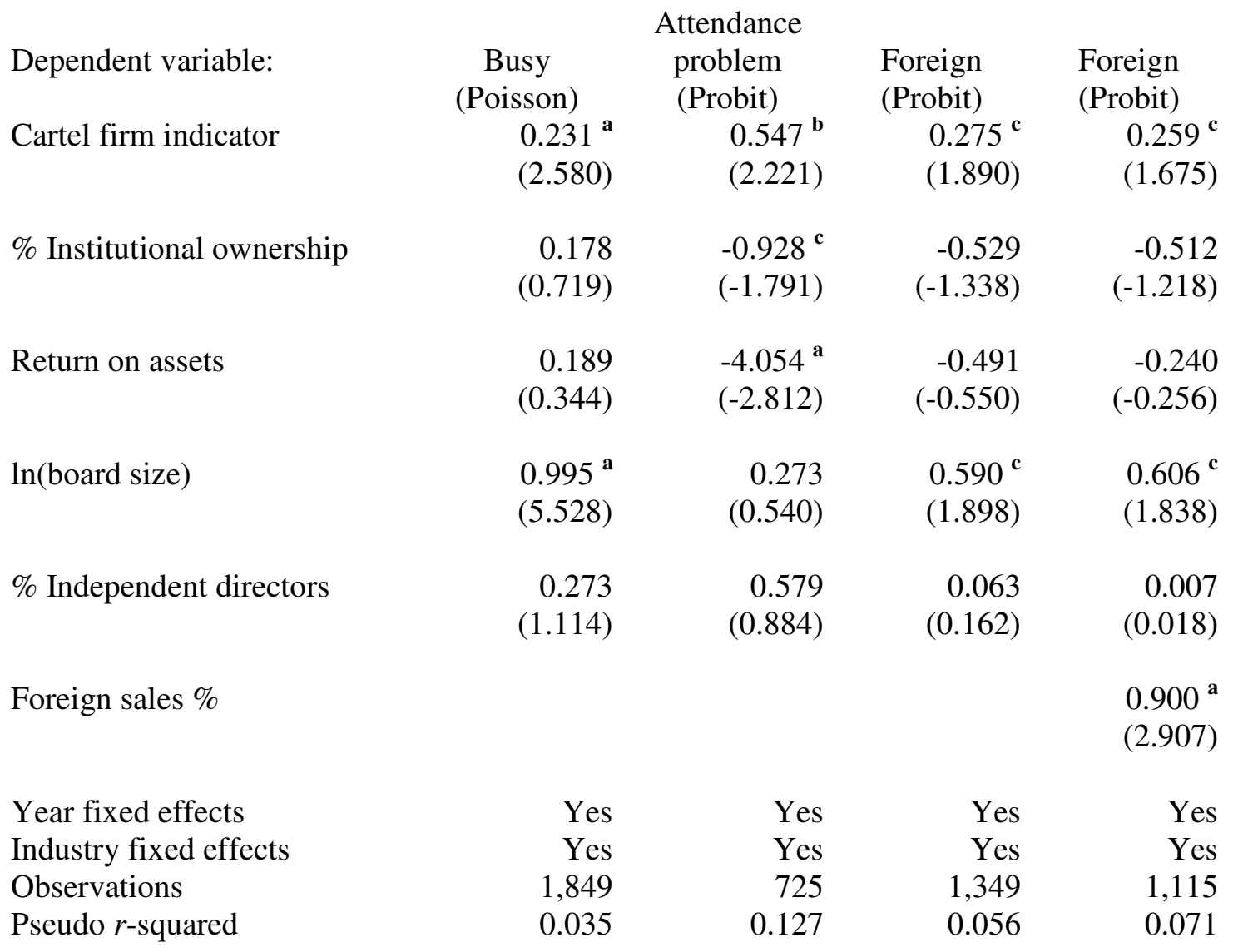

Significant at $1 \%(\mathbf{a}), 5 \%(\mathbf{b})$ and $10 \%$ (c) levels. 


\section{Table 5}

\section{Retention and replacement of CEOs}

The table shows probit regression estimates for models of CEO turnover of replacement. The sample includes 218 U.S. firms identified by regulators as cartel participants between 1986-2010, as well as a control sample of Compustat firms matched on size and industry. The first column presents a model of CEO replacement with the dependent variable equal to 1 if a new CEO takes office. The second column shows estimates for a model in which the dependent variable equals 1 if the new CEO is promoted from within the firm. This estimation is restricted only to those firm-years in which a CEO replacement occurs. The third column presents a model for whether the incumbent CEO, regardless of length of tenure, was originally promoted from within the firm. $t$-statistics appear in parentheses.

Dependent variable:

Cartel firm indicator

$\ln (\mathrm{CEO}$ age $)$

CEO tenure, as of prior year

CEO aged 66 to 72 (indicator)

$\ln ($ total assets)

Growth in sales, prior three years

Return on assets, prior year

Book-to-market, prior year

Number of business segments

Year fixed effects

Industry fixed effects

Observations

Pseudo $r$-squared

Significant at $1 \%($ a), $5 \%(\mathbf{b})$ and $10 \%(\mathbf{c})$ levels.
CEO
replaced

$-0.103^{c}$

$(-1.650)$

$(-1.650)$

$0.016^{\mathrm{a}}$

(4.986)

$0.494^{\mathrm{a}}$

(5.457)

$0.069^{\mathrm{a}}$

(4.123)

$-0.203^{a}$

$(-3.923)$

$-0.606^{b}$

$(-2.018)$

0.009

(0.208)

(0.208)
New CEO promoted inside

$$
0.391^{\mathbf{b}}
$$

$-0.856^{\mathrm{c}}$

Current CEO was promoted inside 


\section{Table 6}

\section{Managers appointed by incumbent CEO}

The table shows Tobit regression estimates of models in which the dependent variable equals the fraction of the top management team appointed by the incumbent CEO. The two alternative definitions of this variable are calculated following Landier et al. (2013) and are based upon how many of the firm's managers appear in the ExecuComp database no earlier than the appointment of the incumbent CEO. The FTA1 measure in the left two columns counts a manager as appointed by the CEO if he has served strictly less time in office than the CEO, which the FTA2 measure in the right two columns counts a manager as appointed by the CEO if his first appearance in ExecuComp coincides with the CEO's first year. The control variable for the fraction of top executives picked in the CEO's first year is based on the number of top managers appointed in the CEO's first year, and it always equals zero by construction for the FTA1 measure. $z$-statistics appear in parentheses.

\begin{tabular}{|c|c|c|c|c|}
\hline \multirow{2}{*}{$\begin{array}{l}\text { Dependent variable: } \\
\text { Cartel firm indicator }\end{array}$} & \multicolumn{2}{|c|}{ FTA1 } & \multicolumn{2}{|c|}{ FTA2 } \\
\hline & $\begin{array}{l}0.028^{\mathbf{b}} \\
(2.210)\end{array}$ & $\begin{array}{l}0.039^{\mathbf{b}} \\
(2.252)\end{array}$ & $\begin{array}{l}0.027^{\mathrm{a}} \\
(2.847)\end{array}$ & $\begin{array}{l}0.034^{b} \\
(2.525)\end{array}$ \\
\hline Inside CEO & $\begin{array}{l}-0.075^{a} \\
(-5.710)\end{array}$ & $\begin{array}{l}-0.166^{a} \\
(-9.386)\end{array}$ & $\begin{array}{l}-0.065^{a} \\
(-6.661)\end{array}$ & $\begin{array}{l}-0.128^{a} \\
(-9.246)\end{array}$ \\
\hline CEO tenure with firm & $\begin{array}{c}0.138^{\mathrm{a}} \\
(58.028)\end{array}$ & $\begin{array}{r}0.118^{\mathrm{a}} \\
(41.645)\end{array}$ & $\begin{array}{r}0.106^{\mathbf{a}} \\
(63.538)\end{array}$ & $\begin{array}{r}0.088^{\mathbf{a}} \\
(40.718)\end{array}$ \\
\hline $\ln (\mathrm{CEO}$ age $)$ & $\begin{array}{r}-0.055 \\
(-1.254)\end{array}$ & $\begin{array}{l}-0.120^{\mathbf{b}} \\
(-2.039)\end{array}$ & $\begin{array}{r}-0.007 \\
(-0.217)\end{array}$ & $\begin{array}{l}-0.075^{c} \\
(-1.665)\end{array}$ \\
\hline Mean executive tenure with firm & $\begin{array}{r}-0.121^{a} \\
(-36.884)\end{array}$ & & $\begin{array}{r}-0.111^{a} \\
(-45.568)\end{array}$ & \\
\hline $\begin{array}{l}\text { Fraction of top executives picked in } \\
\text { the CEO's first year }\end{array}$ & & & $\begin{array}{r}0.646^{\mathbf{a}} \\
(30.135)\end{array}$ & $\begin{array}{r}0.966^{\mathrm{a}} \\
(32.290)\end{array}$ \\
\hline $\ln ($ Firm age $)$ & $\begin{array}{l}0.019^{\mathrm{a}} \\
(3.414)\end{array}$ & $\begin{array}{r}0.005 \\
(0.702)\end{array}$ & $\begin{array}{l}0.019^{\mathrm{a}} \\
(4.713)\end{array}$ & $\begin{array}{r}0.008 \\
(1.307)\end{array}$ \\
\hline $\ln$ (Total assets) & $\begin{array}{l}0.011^{a} \\
(2.989)\end{array}$ & $\begin{array}{l}0.023^{\mathrm{a}} \\
(4.544)\end{array}$ & $\begin{array}{l}0.007^{\mathbf{b}} \\
(2.410)\end{array}$ & $\begin{array}{l}0.015^{\mathrm{a}} \\
(3.845)\end{array}$ \\
\hline Return on assets & $\begin{array}{r}0.026 \\
(0.459)\end{array}$ & $\begin{array}{l}-0.128^{c} \\
(-1.681)\end{array}$ & $\begin{array}{r}0.057 \\
(1.403)\end{array}$ & $\begin{array}{r}-0.060 \\
(-1.029)\end{array}$ \\
\hline Number of business segments & $\begin{array}{r}-0.004 \\
(-1.051)\end{array}$ & $\begin{array}{r}-0.003 \\
(-0.638)\end{array}$ & $\begin{array}{r}-0.002 \\
(-0.971)\end{array}$ & $\begin{array}{r}-0.002 \\
(-0.459)\end{array}$ \\
\hline Year fixed effects & Yes & Yes & Yes & Yes \\
\hline $\begin{array}{l}\text { Industry fixed effects } \\
\text { Observations }\end{array}$ & $\begin{array}{r}\text { Yes } \\
2,526\end{array}$ & $\begin{array}{r}\text { Yes } \\
2,526\end{array}$ & $\begin{array}{r}\text { Yes } \\
2,526\end{array}$ & $\begin{array}{r}\text { Yes } \\
2,526\end{array}$ \\
\hline LR Chi-squared & $3225.938^{\mathrm{a}}$ & $2040.732^{a}$ & $3968.948^{a}$ & $2340.568^{\mathrm{a}}$ \\
\hline Prob > Chi-squared & 0.000 & 0.000 & 0.000 & 0.000 \\
\hline
\end{tabular}

Significant at $1 \%($ a), $5 \%$ (b) and $10 \%$ (c) levels. 


\section{Table 7}

\section{Changes in auditors}

The table reports the results from probit regressions of a dummy variable that equals 1 when the firm changes auditors in a given year. The sample includes 218 U.S. firms identified by regulators as cartel participants between 1986-2010, as well as a control sample of Compustat firms matched on size and industry. Auditor changes are identified from Compustat. The sample excludes a small number of observations for firms that do not have Big 4 auditors. $z-$ statistics appear in parentheses.

Dependent variable:

Cartel firm indicator

Growth in ROA, prior three years, $\times 10^{-2}$

Growth in total assets, prior three years, $\times 10^{-2}$

$\ln ($ Total assets)

Year fixed effects

Industry fixed effects

Observations

Pseudo $r$-squared
Company changes auditor

$$
\begin{array}{ll}
-0.196^{\mathbf{b}} & -0.164^{\mathbf{c}} \\
(-2.232) & (-1.806)
\end{array}
$$

$$
0.278 \quad 0.268
$$

$0.102 \quad 0.051$

$-0.039^{\mathrm{a}} \quad-0.068^{\mathrm{a}}$

$\begin{array}{rr}\text { Yes } & \text { Yes } \\ \text { No } & \text { Yes } \\ 10,308 & 10,213 \\ 0.111 & 0.134\end{array}$

Significant at $1 \%$ (a), 5\% (b) and 10\% (c) levels. 


\section{Table 8}

\section{Contributions to political candidates}

The table reports regression estimates of models of contributions to political candidates by corporate political action committees (PACs). In the left column, the dependent variable equals the log of the total dollar value contributed per year by each company. In the center column, the dependent variable is a binary indicator for nonzero political contributions by the company. In the right column, the dependent variable is the log of the political index, defined by Cooper et al. (2010) to equal the total number of supported candidates over the previous five years. The sample includes 218 U.S. firms identified by regulators as cartel participants between 1986-2010, as well as a control sample of Compustat firms matched on size and industry. .t-statistics appear in parentheses.

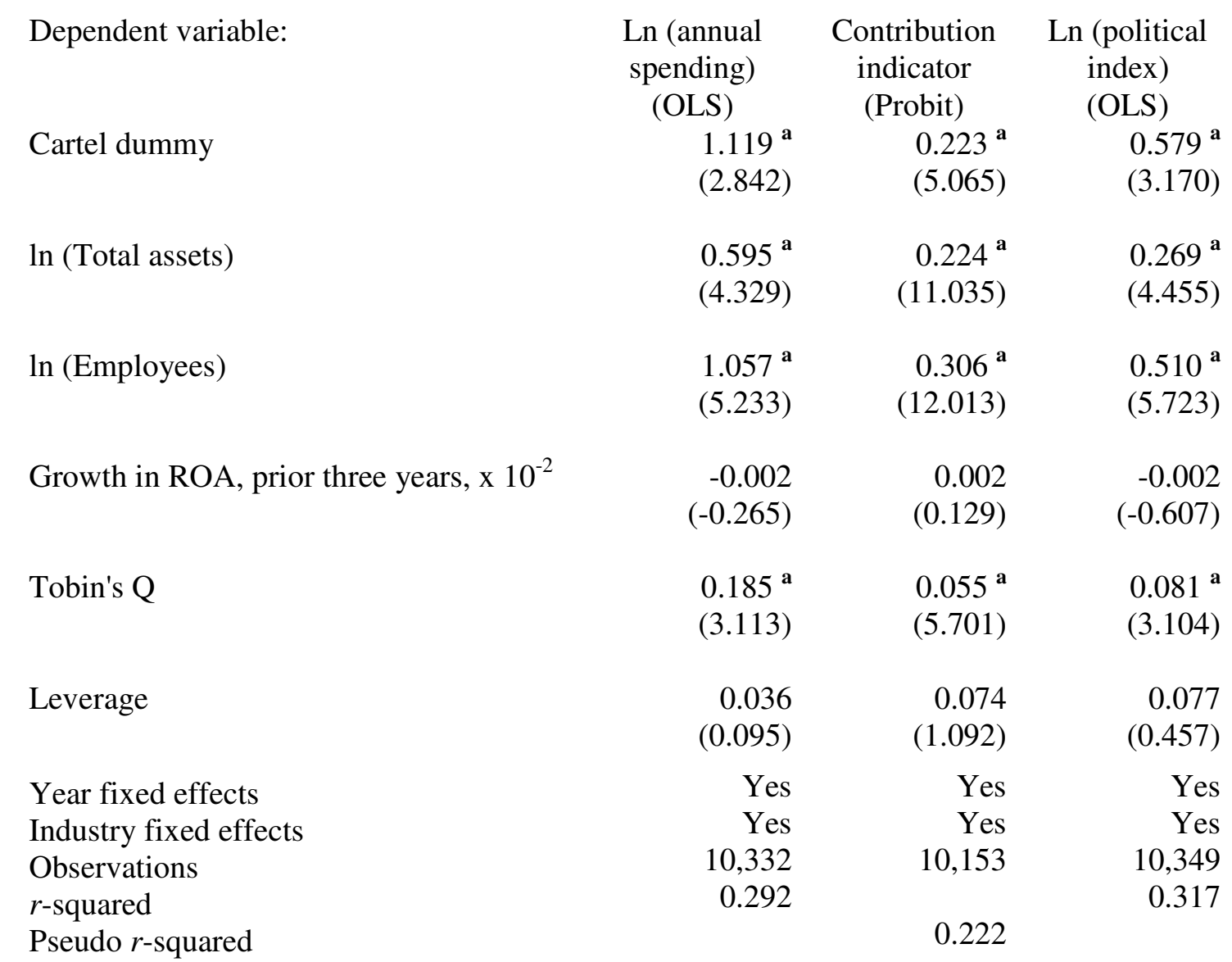

Significant at $1 \%(\mathbf{a}), 5 \%$ (b) and $10 \%$ (c) levels. 


\section{Table 9}

\section{Restatements}

The table reports probit regression estimates for whether a firm restates its audited financial statements for a given year and Poisson regression estimates of the number of restatements per year. The sample includes 218 U.S. firms identified by regulators as cartel participants between 1986-2010, as well as a control sample of Compustat firms matched on size and industry. Regressions include control variables following the definitions in Larcker, Richardson and Tuna (2007). Data for restatements is obtained from the Audit Analytics database, which covers restatements disclosed since January 1, 2001, and due to the coverage of this database we use observations only for the years 2000-2010. $z$-statistics appear in parentheses.

Dependent variable:

\begin{tabular}{|c|c|c|c|c|}
\hline \multirow[b]{2}{*}{ Cartel firm indicator } & \multicolumn{2}{|c|}{ (Probit) } & \multicolumn{2}{|c|}{$\begin{array}{c}\text { restated } \\
\text { (Poisson) }\end{array}$} \\
\hline & $\begin{array}{l}0.335^{\mathrm{a}} \\
(3.717)\end{array}$ & $\begin{array}{l}0.245^{b} \\
(2.426)\end{array}$ & $\begin{array}{l}0.628^{a} \\
(4.494)\end{array}$ & $\begin{array}{l}0.371^{\mathrm{b}} \\
(2.509)\end{array}$ \\
\hline Book-to-market ratio (lagged) & $\begin{array}{l}0.114^{\mathbf{b}} \\
(2.067)\end{array}$ & $\begin{array}{l}0.127^{\mathbf{b}} \\
(2.012)\end{array}$ & $\begin{array}{l}0.230^{\mathbf{b}} \\
(2.406)\end{array}$ & $\begin{array}{l}0.220^{b} \\
(2.261)\end{array}$ \\
\hline Ln(market capitalization) (lagged) & $\begin{array}{r}-0.007 \\
(-0.335)\end{array}$ & $\begin{array}{r}-0.026 \\
(-0.948)\end{array}$ & $\begin{array}{r}-0.017 \\
(-0.441)\end{array}$ & $\begin{array}{r}-0.022 \\
(-0.512)\end{array}$ \\
\hline External financing & $\begin{array}{r}-0.096 \\
(-0.619)\end{array}$ & $\begin{array}{r}-0.230 \\
(-1.292)\end{array}$ & $\begin{array}{r}-0.163 \\
(-0.633)\end{array}$ & $\begin{array}{r}-0.353 \\
(-1.280)\end{array}$ \\
\hline Acquisitions / market capitalization & $\begin{array}{r}-0.211 \\
(-0.393)\end{array}$ & $\begin{array}{r}-0.072 \\
(-0.125)\end{array}$ & $\begin{array}{r}-0.698 \\
(-0.733)\end{array}$ & $\begin{array}{r}-0.215 \\
(-0.225)\end{array}$ \\
\hline Free Cash Flow & $\begin{array}{r}0.063 \\
(0.441)\end{array}$ & $\begin{array}{r}-0.157 \\
(-0.917)\end{array}$ & $\begin{array}{r}0.246 \\
(1.040)\end{array}$ & $\begin{array}{r}-0.167 \\
(-0.669)\end{array}$ \\
\hline $\begin{array}{l}\text { Year fixed effects } \\
\text { Industry fixed effects } \\
\text { Observations } \\
\text { Pseudo } r \text {-squared }\end{array}$ & $\begin{array}{r}\text { No } \\
\text { No } \\
2,164 \\
0.013\end{array}$ & $\begin{array}{r}\text { Yes } \\
\text { Yes } \\
1,911 \\
0.096\end{array}$ & $\begin{array}{r}\text { No } \\
\text { No } \\
2,164 \\
0.016\end{array}$ & $\begin{array}{r}\text { Yes } \\
\text { Yes } \\
2,164 \\
0.135\end{array}$ \\
\hline
\end{tabular}

Significant at $1 \%$ (a), $5 \%$ (b) and $10 \%$ (c) levels. 


\section{Table 10}

\section{Earnings smoothing}

The table reports the results from a variance ratio test that compares the standard deviations of regression residuals for subsamples of observations used to estimate earnings smoothing models. In the left column, statistics are based on residuals from the model shown in equation (1), with observations for 218 cartel firms pooled together with observations from a control sample of Compustat firms matched on size and industry. In the right column, statistics are based on residuals from a similar regression that also includes interaction terms between all control variables and an indicator that equals one for cartel firms. Results in the fourth line of the table show the outcome of $F$-tests for the null hypothesis that the variance ratios equal one. Rejection of the null hypothesis in both is robust to the use of alternative Levene and Brown-Forsythe test statistics.

\section{Pooled regression}

Control firm observations' residual std. dev. Cartel firm observations' residual std. dev.

\section{Ratio}

$F$-test $p$-value for $\mathrm{H}_{0}$ : Ratio $=1$

$t$-test $p$-value for equality of means

Observations

$\begin{array}{rr}0.119 & 0.119 \\ 0.109 & 0.061 \\ 1.089 & 1.960 \\ 0.000^{\mathbf{a}} & 0.000^{\mathbf{a}} \\ 0.035^{\mathbf{b}} & 0.389 \\ 10,589 & 10,589\end{array}$

0.003

0.001

0.001
0.000

0.000

Pooled regression with interaction

0.119

$.000^{\mathrm{a}}$

0,589

0.000

Significant at $1 \%(\mathbf{a}), 5 \%(\mathbf{b})$ and $10 \%$ (c) levels. 


\section{Table 11}

\section{Earnings management}

The table reports ordinary least squares regression estimates of discretionary accruals and revenue recognition. The sample includes 218 U.S. firms identified by regulators as cartel participants between 1986-2010, as well as a control sample of Compustat firms matched on size and industry. Following Bergstresser and Philippon (2006) and Klein (2002), the discretionary accruals are constructed according to the crosssectional Jones (Column 1) and the cross-sectional modified Jones models (Column 2). The measure of deferred revenue is the ratio of Compustat items DRC+DRLT divided by net sales. DRC is revenue which has not yet been earned, but is expected to be classified as earned during the current year, while DRLT is revenue which has not yet been earned. The model in the sixth column uses a binary dependent variable that equals 1 if the sum of the sum of DRC+DRLT is greater than zero. $t$-statistics appear in parentheses and in the first two columns are based on the clusterrobust variant of the Huber-White sandwich estimator. 


\section{Dependent variable:}

Cartel firm indicator

$\ln$ (total assets)

(total assets)

Leverage

$\ln ($ firm age)

Tobin's $Q$

Absolute value of change in EBIT x $10^{-2}$

Year fixed effects

Industry fixed effects

Observations

$r$-squared

Pseudo $r$-squared

LR Chi-squared

Prob $>$ Chi-squared

Significant at $1 \%(\mathbf{a}), 5 \%(\mathbf{b})$ and $10 \%$ (c) levels.
Discretionary accruals

$$
\text { Jones Modified Jones }
$$

(OLS)

$$
0.010^{\mathrm{a}}
$$

(2.319)

(OLS)

$-0.001$

$(-1.073)$

0.008

(1.137)

$$
0.003^{\mathrm{c}}
$$

(1.734)

0.000

$(0.184)$

$-0.003$

$(-1.340)$

Yes

Yes

8,008

0.026

$$
0.007
$$

(1.606)

$-0.002$

$(-1.168)$

0.003

(0.356)

0.001

(0.361)

$0.003^{\mathrm{c}}$

(1.928)

$-0.003$

$(-1.517)$

Yes

Yes

8,002

0.022
Abs(discretionary accruals)

Jones

(Tobit)

$$
0.07^{\mathbf{b}}
$$

(2.115)

$-0.009^{\mathrm{a}}$

$(-9.992)$

0.009

(1.634)

$-0.006^{a}$

(-5.011)

$0.003^{\mathrm{a}}$

(4.553)

$-0.001$

$(-0.272)$

Yes

Yes

8,008

$961.387^{\mathrm{a}}$
0.000

$$
\text { Modified Jones }
$$

(Tobit)

$$
0.012^{\mathrm{a}}
$$

(3.120)

$-0.010^{a}$

(-10.375)

0.009

(1.594)

$-0.006^{\mathrm{c}}$

$(-4.923)$

$0.004^{\mathrm{a}}$

(5.470)

$-0.001$

(-0.341)

Yes

Yes

8,002

0.056

$949.056^{\mathrm{a}}$
0.000
Deferred revenue

Amount Indicator

Amount

$-0.073^{a}$

$(-4.511)$

(Probit)

$-0.350^{\mathbf{a}}$

(-4.799)

$-0.012^{\mathrm{a}}$

0.008

$(-3.107)$

(0.406)

$-0.118^{a} \quad-0.899^{a}$

$(-4.811) \quad(-7.202)$

$-0.030^{\mathbf{a}} \quad-0.124^{\mathbf{a}}$

(-4.898) (-4.359)

$\begin{array}{lr}0.010^{\mathbf{b}} & 0.032 \\ (2.264) & (1.494)\end{array}$

$\begin{array}{rr}0.006 & 0.507 \\ (0.878) & (1.416) \\ \text { Yes } & \text { Yes } \\ \text { Yes } & \text { Yes } \\ 3,349 & 3,250 \\ & 0.189\end{array}$

$756.859^{a}$

0.000 


\section{Table 12}

\section{Change in Herfindahl Hirschman Index}

The table reports the results from tobit regressions of the absolute value of the annual change in the intra-firm Herfindahl Hirschman Index based on total assets. The sample includes 218 U.S. firms identified by regulators as cartel participants between 1986-2010, as well as a control sample of Compustat firms matched on size and industry. The index is calculated from annual industry segment data reported by each company. $t$-statistics appear in parentheses.

Dependent variable:

Change in HHI (total assets)

Cartel firm indicator $0.014^{\mathrm{a}} \quad 0.010^{\mathrm{b}}$ (2.928) (2.206)

Growth rate of return on assets, prior three years $\times 10^{-3}$

Leverage

$0.027^{\mathrm{a}} \quad 0.039^{\mathrm{a}}$

Intangible assets / total assets

Capital expenditures / total assets

$\ln$ (Total assets)

$$
0.006^{\mathrm{a}} \quad 0.009^{\mathrm{a}}
$$

Year fixed effects

Industry fixed effects

Observations

LR Chi-squared

Prob $>$ Chi-squared

$\begin{array}{rr}\text { Yes } & \text { Yes } \\ \text { No } & \text { Yes } \\ 7,275 & 7,275^{\mathbf{a}} \\ 341.987^{\mathbf{a}} & 517.885^{\mathbf{a}} \\ 0.000 & 0.000\end{array}$

Significant at $1 \%$ (a), 5\% (b) and $10 \%$ (c) levels. 


\section{Table 13}

\section{Stock option exercises by top executives}

The table reports Tobit regression estimates for the value realized from options exercised over the intrinsic value of exercisable options (Columns 1 and 3 ) and the number of options exercised over total exercisable options (Columns 2 and 4). In the right two columns, the dependent variables are calculated as the mean within the group of top five executives for each company. The sample includes 218 U.S. firms identified by regulators as cartel participants between 1986-2010, as well as a control sample of Compustat firms matched on size and industry. Option exercise data is obtained from ExecuComp, while information about the inventory and value of exercisable options is obtained from Compustat. Regressions include control variables for options outstanding, past stock performance, Tobin's $Q$ and average industry exercises, which is calculated as the average value of the dependent variable for all firms in the same two-digit SIC industry with data on ExecuComp in that year. All control variables are lagged by one year. All regressions include year fixed effects. $t$-statistics appear in parentheses.

Dependent variable:

Cartel firm indicator

Average industry exercises

Options outstanding x $10^{-2}$

Prior year return to shareholders

Tobin's $Q$

Year fixed effects

Industry fixed effects

Observations

LR Chi-squared

Prob > Chi-squared

\section{Value realized /}

intrinsic value of exercisable options

$$
0.086^{\mathrm{a}}
$$

(3.549)

$0.349^{\mathrm{a}}$

(2.617)

0.010

(1.083)

0.002

(0.386)

$0.024^{\mathrm{a}}$

(4.189)

Yes

Yes

3,230

$93.948^{\mathrm{a}}$

0.000
Options exercised /

exercisable options

$0.032^{\mathrm{c}}$

(1.889)

$0.605^{\mathrm{a}}$

(4.636)

$-0.009$

(-1.253)

0.004

(1.446)

$0.037^{\mathrm{a}}$

(8.973)

Yes

Yes

3,629

$170.407^{\mathrm{a}}$

0.000
Top 5 executives

Value realized /

intrinsic value of Options exercised /

exercisable options exercisable options

$$
0.033^{\text {b }} \quad 0.002
$$

$0.241^{\mathrm{a}}$

$0.523^{\mathrm{a}}$

(7.674)

(3.088)

$-0.013^{a}$

0.006

$(-3.486)$

$-0.003$

(-1.033)

$-0.000$

$(-0.021)$

$0.013^{\mathrm{a}}$

$0.026^{\mathrm{a}}$

(3.993)

(11.851)

Yes

Yes
3,532

$175.685^{\mathrm{a}}$

0.000
Yes

Yes
3,788

$336.669^{\mathrm{a}}$

Significant at $1 \%(\mathbf{a}), 5 \%(\mathbf{b})$ and $10 \%$ (c) levels. 


\section{Table 14}

\section{Securities fraud litigation}

The table reports the results from regressions for the incidence of securities fraud lawsuits filed during the period 1996-2010, based on the Stanford Law School Securities Class Action Clearinghouse. The sample includes 218 U.S. firms identified by regulators as cartel participants between 1986-2010, as well as a control sample of Compustat firms matched on size and industry. $t$-statistics appear in parentheses.

Dependent variable: $\quad$ Fraud lawsuit indicator Number of fraud lawsuits (Probit) (Poisson)

$\begin{array}{lrr}\text { Cartel firm indicator } & 0.311^{\mathbf{a}} & 0.809^{\mathbf{a}} \\ & (3.674) & (4.695) \\ \text { Return on assets } & -0.801^{\mathbf{a}} & -1.518^{\mathbf{a}} \\ & (-3.903) & (-4.226) \\ & & \\ \ln \text { (Total assets) } & 0.167^{\mathbf{a}} & 0.345^{\mathbf{a}} \\ & (6.639) & (6.376) \\ \text { Year fixed effects } & \text { Yes } & \text { Yes } \\ \text { Industry fixed effects } & \text { Yes } & \text { Yes } \\ \text { Observations } & 6,897 & 8,115 \\ \text { Pseudo } r \text {-squared } & 0.090 & 0.130\end{array}$

Significant at $1 \%(\mathbf{a}), 5 \%(\mathbf{b})$ and $10 \%$ (c) levels. 


\section{Figure 1}

\section{Return on assets around the year of cartel formation}

The figure shows mean annual return on assets for 218 U.S. companies participating in pricefixing cartels. Year 0 represents the beginning of each cartel according to government antitrust regulators. The sample is identified by Connor (2010) from government filings, press releases, and news reports.

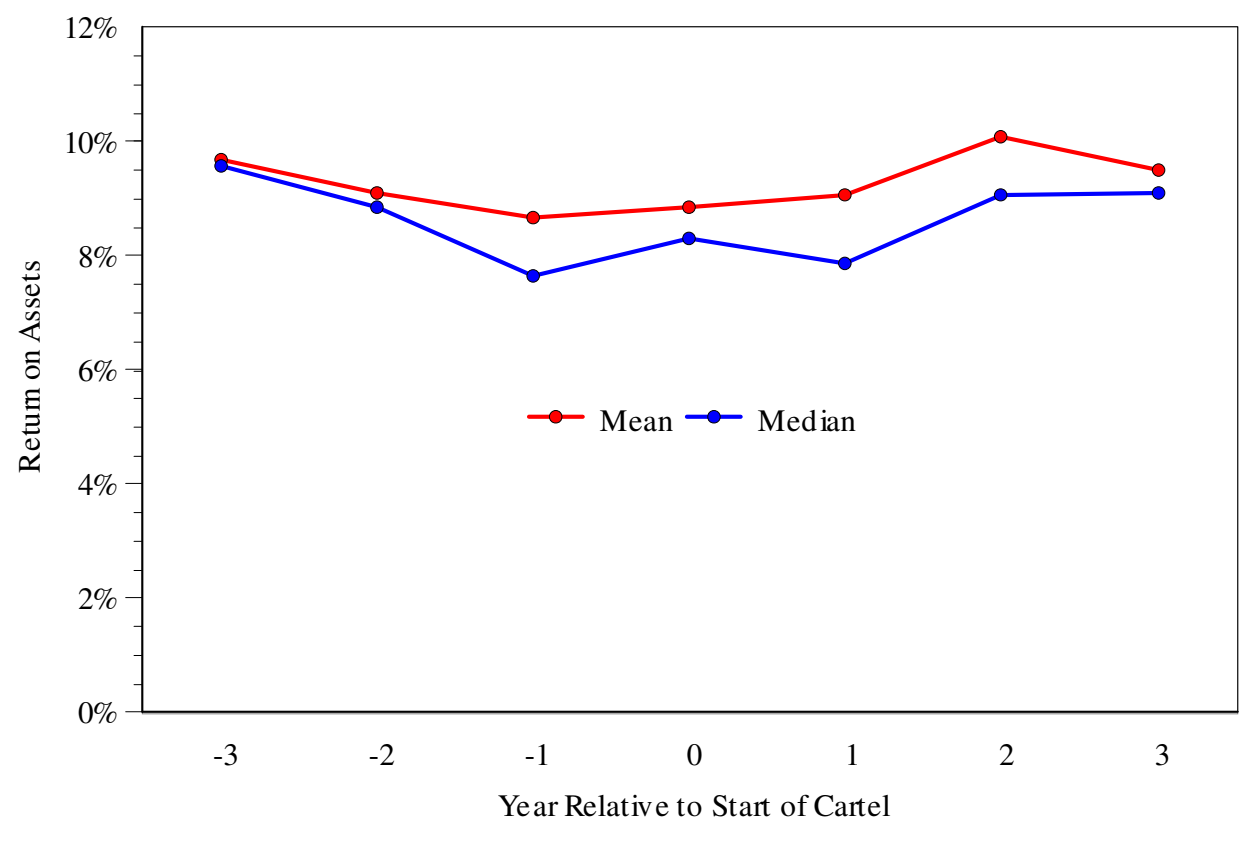

